UDK 902

ISSN 1330-0644

VOL 36/2019.

ZAGREB, 2019.

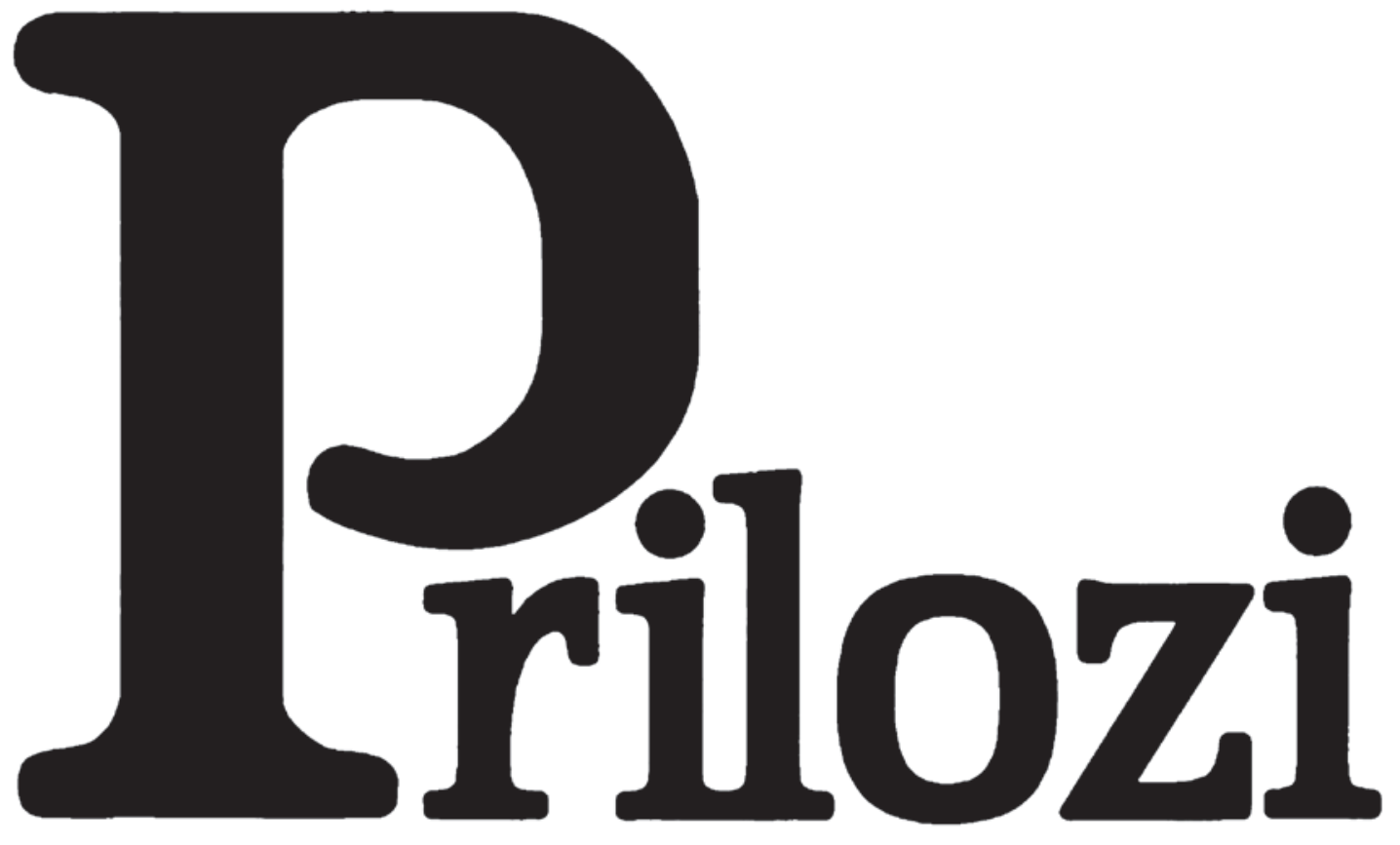

Instituta za arheologiju u Zagrebu 
Pril. Inst. arheol. Zagrebu, 36/2019

Str./Pages 1-196, Zagreb, 2019.
Izdavač/Publisher

INSTITUT ZA ARHEOLOGIJU

INSTITUTE OF ARCHAEOLOGY

Adresa uredništva/Address of the editor's office

Institut za arheologiju/Institute of archaeology

HR-10000 Zagreb, Ulica Ljudevita Gaja 32

Hrvatska/Croatia

Telefon/Phone ++385/(0)1 6150250

Fax $++385(0) 16055806$

e-mail: urednistvo.prilozi@iarh.hr

http://www.iarh.hr

Glavni i odgovorni urednik/Editor in chief

Marko DIZDAR

Uredništvo/Editorial board

Marko DIZDAR, Snježana KARAVANIĆ, Viktória KISS (Budapest, HUN) (prapovijest/Prehistory), Goranka LIPOVAC VRKLJAN (antika/Antiquities), Tajana SEKELJ IVANČAN, Katarina Katja PREDOVNIK (Ljubljana, SLO), Natascha MEHLER (Wien, AUT), Juraj BELAJ, Tatjana TKALČEC (srednji vijek i novi vijek/Middle Ages and Modern era), Predrag NOVAKOVIĆ (Ljubljana, SLO) (metodologija/Methodology)

Izdavački savjet/Editorial advisory board

Dunja GLOGOVIĆ (Zagreb), Ivor KARAVANIĆ (Zagreb), Laszlo KÓVACS (Budapest, HUN),

Kornelija MINICHREITER (Zagreb), Mladen RADIĆ (Osijek), Aleksandar RUTTKAY (Nitra, SK), Ivančica SCHRUNK (Minneapolis, USA), Željko TOMIČIĆ (Zagreb), Ante UGLEŠIĆ (Zadar)

Prijevod na engleski/English translation

Ivan ARBANAS, Marko BANDA, Domagoj BUŽANIĆ, Mario CARIĆ, Marko MARAS, Andreja MAVER, Goran TOMAC, Mirna VUKOV

Lektura/Language editor

Ivana MAJER (hrvatski jezik/Croatian)

Marko MARAS (engleski jezik/English)

Korektura/Proofreads

Katarina BOTIĆ

Marko DIZDAR

Grafičko oblikovanje/Graphic design

Roko BOLANČA

Računalni slog/Layout

Hrvoje JAMBREK

Tisak/Printed by

Tiskara Zelina d.d., Sv. I. Zelina

Naklada/Issued

400 primjeraka/400 copies

Prilozi Instituta za arheologiju u Zagrebu uključeni su u sljedeće indekse/ Prilozi Instituta za arheologiju u Zagrebu are included in following indices:

DYABOLA - Sachkatalog der Bibliothek - Römisch-Germanische Kommission des Deutschen Archaeologischen Instituts, Frankfurt a. Main

Clarivate Analytics services - Emerging Sources Citation Index

CNRS/INIST - Centre National de la Recherche Scientifi que/L'Institut de I'Information Scientifi que et Technique, Vandoeuvre-lès-Nancy

EBSCO - Information servises, Ipswich

ERIH - European Reference Index for the Humanities, European Science Fundation, Strasbourg SciVerse Scopus - Elsevier, Amsterdam 
Sadržaj

\section{Izvorni znanstveni radovi}

MARKO BANDA

IVOR KARAVANIĆ

Mustjerska industrija špilje Veternice

41

\author{
RAJNA ŠOŠIĆ KLINDŽIĆ \\ HRVOJE KALAFATIĆ \\ BARTUL ŠILJEG \\ TOMISLAV HRŠAK
}

Krugovi i keramika kroz stoljeća: značajke naselja

sopotske kulture

\section{DARIA LOŽNJAK DIZDAR}

Status žena u podunavskim zajednicama u starijem željeznom dobu -

Primjer groba 1 iz Sotina

121

MIRJANA SANADER

MIRNA VUKOV

DOMAGOJ BUŽANIĆ

Pax Romana između Burna i Tilurija.

Krajolik sukoba?

135 MITJA GUŠTIN

The belt-buckle with Bacchus from "Romuliana"

143 MAJA BAUSOVAC

Kasnorimski lonci za pohranu s T-oblikom ruba iz Rifnika kod Celja

\section{Contents}

\section{Original scientific papers}

\author{
MARKO BANDA \\ IVOR KARAVANIĆ \\ The Mousterian industry of Veternica Cave
}

\author{
RAJNA ŠOŠIĆ KLINDŽIĆ \\ HRVOJE KALAFATIĆ \\ BARTUL ŠILJEG \\ TOMISLAV HRŠAK \\ Circles and ceramics through the centuries: \\ Characteristics of Neolithic Sopot culture settlements
}

\section{DARIA LOŽNJAK DIZDAR}

Status of women in the Danube Basin communities in the Early Iron Age-

Example of grave 1 from Sotin

\section{MIRJANA SANADER \\ MIRNA VUKOV \\ DOMAGOJ BUŽANIĆ}

Pax Romana between Burnum and Tilurium.

Landscape of conflicts?

\section{MITJA GUŠTIN}

Pojasna kopča s Bakhom iz „Romuliane”

MAJA BAUSOVAC

Late Roman storage jars with a T-shaped rim from Rifnik near Celje, Slovenia 
BRINA ZAGORC

DARIA LOŽNJAK DIZDAR

ANITA RAPAN PAPEŠA

ANDREA RIMPF

MISLAV ČAVKA

IVOR JANKOVIĆ

MARIO NOVAK

Bioarheologija kasnoavarske populacije iz nalazišta

Šarengrad - Klopare: preliminarni rezultati

\section{Prikazi}

KREŠIMIR MIJIĆ

Tomislav Fabijanić, Miroslav Glavičić, Mirko Rašić, Kulturno povijesna baština općine Ljubuški: Zbornik radova

KREŠIMIR MIJIĆ

Irena Radić Rossi - Giulia Boetto (ur.), Pakoštane - Veli Školj: Kasnoantički brodolom u geološkogeografskom i kulturno-povijesnom kontekstu
MARIO CARIĆ

BRINA ZAGORC

DARIA LOŽNJAK DIZDAR

ANITA RAPAN PAPEŠA

ANDREA RIMPF

MISLAV ČAVKA

IVOR JANKOVIĆ

MARIO NOVAK

Bioarchaeology of the Late Avar population from Šarengrad - Klopare: preliminary results

\section{Book reviews}

\section{KREŠIMIR MIJIĆ}

Tomislav Fabijanić, Miroslav Glavičić, Mirko Rašić, The Culture-historical Heritage of the municipality of Ljubuški: The Collection of Papers

\section{KREŠIMIR MIJIĆ}

Irena Radić Rossi - Giulia Boetto (eds.), Pakoštane - Veli Školj: The Late Roman Shipwreck in Its Geological-geographic and Cultural-historical Context 


\title{
Pax Romana između Burna i Tilurija. Krajolik sukoba?
}

\section{Pax Romana between Burnum and Tilurium. Landscape of conflicts?}

\author{
Izvorni znanstveni rad \\ Antička arheologija \\ Original scientific paper \\ Roman archaeology \\ UDK/UDC 904:355.312(497.58)"652" \\ Primljeno/Received: 25. 01. 2019. \\ Prihvaćeno/Accepted: 31. 07. 2019.
}

\author{
MIRJANA SANADER \\ MIRNA VUKOV \\ DOMAGOJ BUŽANIĆ \\ Odsjek za arheologiju, \\ Filozofski fakultet Sveučilišta u Zagrebu \\ Ivana Lučića 3 \\ HR-10000 Zagreb \\ msanader@ffzg.hr \\ mvukov@ffzg.hr \\ dbuzanic@ffzg.hr
}

\begin{abstract}
Na području između Burna i Tilurija odvijala se od 6. do 9. godine jedna od posljednjih faza delmatsko-panonskog ustanka. Taj ustanak, poznat pod imenom Bellum Batonianum, dobio je ime po Batonima, vođama pobunjenika. O kakvom se sukobu radilo i koliko je on uzdrmao rimsku državu najbolje svjedoče Svetonijeve riječi u Tiberijevoj biografiji (Suet. Tib. 16.1): ...gravissimum omnium externorum bellorum post Punica. Tekje nakon savladavanja ustanika u rimskoj provinciji Dalmaciji moglo započeti razdoblje istinskoga mira (Pax Romana) koji je, osim toga, bio blagodatan i za Italiju kojoj je ova čuvala priobalne prilaze. Mirnodopsku blagodat na prostoru između Burna i Tilurija Rimljani su postigli strateškim razmještanjem legionarskih i pomoćnih vojnih jedinica. Ovaj rad želi istražiti da li u tome prostornom razmještaju trupa ima sustava i da li je u tome sustavu tijekom 1. stoljeća od značenja bio i raspored pomoćnih trupa.*
\end{abstract}

Ključne riječi: Pax Romana, Dalmacija, Burnum, Tilurium, rimska vojska

One of the last stages of the Delmataean-Pannonian rebellion took place in the area between Burnum and Tilurium between 6 and 9 AD. This revolt is known as the Bellum Batonianum, which was named after the two leaders of the rebellion. Suetonius' words in Tiberius's biography (Suet. Tib. 16.1) ...gravissimum omnium externorum bellorum post Punica, best attest to the nature of the conflict and how much it affected the Roman state. In the Roman province of Dalmatia, true peace, the so-called Pax Romana, could have begun only after overpowering the rebels. This peace was also very beneficial to Italy, which was secured by Dalmatian coastal routes. The benefit of peace was achieved by the Romans through the strategic deployment of legionary and auxiliary military units in the area between Burnum and Tilurium. This paper seeks to explore whether the spatial arrangement of units had a certain system and whether the spatial arrangement of auxiliary units during the 1st century had any significance in that system.*

Keywords: Pax Romana, Dalmatia, Burnum, Tilurium, Roman military

\section{KRAJOLIK I CESTE}

Od kada su Rimljani po prvi puta pokazali zanimanje za teritorijem kojega obrađuje ovaj rad, a kojega su u to vrijeme nazivali Ilirikom, pa do njegovoga potpunog osvajanja prošla su stoljeća.' Slijedom učvršćivanja osvojenih pozicija, Rimljani su na strateški važnim položajima podizali logore

1 O osvajanju Ilirika vidi: Wilkes 1969: 13-77; Zaninović 1996a: 209-220; Sanader 2009: 23-32; Matijašić 2009.

* Ovaj rad je prošireno i prepravljeno izlaganje koje su autori pod istim naslovom održali u svibnju 2019. godine u Puli na skupu Past, Present, Future 2019: Peace in History. Avoiding War and the Quest for the Social Justice. Ovaj rad financirala je Hrvatska zaklada za znanost projektom „Razumijevanje rimskih granica: primjer istočnog Jadrana“ (IP-201801-4934).

\section{LANDSCAPE AND ROADS}

Centuries have passed since the Romans have first shown interest in the territory analyzed in this paper, which they then called Illyricum, and its complete conquest. ${ }^{1}$ To consolidate the conquered territories, the Romans raised legionary fortresses and auxiliary forts in strategically impor-

1 About the conquest of Illyricum see: Wilkes 1969: 13-77; Zaninović 1996a: 209-220; Sanader 2009: 23-32; Matijašić 2009.

* This work is an expanded and revised presentation that the authors under the same title, in May 2019, held in Pula at the conference Past, Present, Future 2019: Peace in History. Avoiding War and the Quest for the Social Justice. This work has been fully supported by the Croatian Science Foundation under the project "Understanding Roman Borders. The Case of the Eastern Adriatic" (IP-2018-01-4934). 
za legionare i kastele za pomoćne trupe. Tako su i u zaleđu Jadera i Salone, važnih i prosperitetnih gradova, izgradili dva stalna logora za smještaj legija, a između njih auksilijarne kastele za pomoćne trupe. Radi se o legijskome logoru Burn (Burnum), smještenome poviše rijeke Krke (Titius flumen) u okolici Ivoševaca i Tiluriju (Tilurium), danas selo Gardun, poviše rijeke Cetine (Hyppus flumen). ${ }^{2}$

U krškoj geomorfologiji širega prostora Burna i Tilurija razlikuju se tri strukture krajolika. To su (1) otoci, čiji smjer pružanja prati smjer pružanja planinā na kopnu zbog čega pripadaju tipu kontinentskih otoka, zatim (2) izduženi, uski primorski pojas te (3) brdovita područja u unutrašnjosti koje omeđuju planinski nizovi Velebita, Dinare i Kamešnice (Radić Rossi 2017: 549-576). Tokovi rijeka koje se ulijevaju u Jadransko more učinili su dijelove kopna oko njih kao i njihova ušća vrlo plodnim. Među rijekama, a na prostoru koji nas u ovoj prilici zanima, ističu se rijeke Krka i Cetina. Te su rijeke učinile svoj okoliš plodnim, pa se tako u zaleđu Jadera prostiru ravnice Ravnih kotara, a u zaleđu Salone Sinjsko polje. ${ }^{3}$ Rijeke nisu samo obogaćivale tlo, već su isto tako predstavljale i prirodnu zapreku putnim pravcima. Važnost putnih pravca primijećena je, naravno, i u najdavnijim vremenima, pa je i Rimljanima bilo jasno da preko ove dvije rijeke vode komunikacije od izuzetne važnosti kako za promet roba, tako i za protok ljudi.

Slijedom učvršćivanja i osiguravanja položaja, Rimljani su novoosvojeno područje vrlo brzo počeli povezivati planskom izgradnjom cesta na čiju je topografiju najveći utjecaj imala upravo njegova geomorfološka struktura. Magistralna cesta Aquileia - Dyrrhachium koja je povezivala zapad i istok Carstva, a koja se protezala uzduž istočne strane Jadranske obale, nije mogla prolaziti najkraćim putem koji je uz samu obalu. Razlog tome su kamena podnožja planinskih masiva koja su dopirala do samoga mora. Stoga su ceste išle njihovom sjevernom stranom gdje je prohodnost bila znatno bolja. S naseljima uz obalu ta je magistralna cesta komunicirala preko planinskih prijevoja uz pomoć brojnih sporednih cesta (Bojanovski 1974; Miletić 1993: 117-150; 2006: 125-136). Rimljani su se prilikom postavljanja pojedinih prometnih pravaca poslužili postojećim komunikacijama lokalnoga stanovništva jer su te predrimske komunikacije, ne samo u provinciji Dalmaciji nego i u drugim provincijama u Carstvu, bile uglavnom najbolje rješenje. Pokazalo se da su zatečene

2 Najraniji opis rimskoga vojnog logora sačuvao se u spisima grčkoga povjesničara Polibija (VI,39) iz 2. st. pr. Kr. Njegov pokretni logor imao je shemu pravokutnika zaštićenoga jarkom i nasipom s prsobranom. Vojnici su noćili u šatorima od kože. Arhitekturi logora posvetio se Hygin ( $D e$ mun. castr. 16) koji je preporučio odnos dužine prema širini logora u omjeru 1:3. Prvi stalni logori bili su sagrađeni od drva, da bi se od sredine 1. st. poslije Krista počeli graditi, barem djelomično, i od kamena. Njihovi su tlocrti uglavnom bili isti, no razlikovali su se po veličini, pri čemu su manji bili za smještaj auksilijarnih jedinica, a veći za legionare. Svi su logori imali bedeme učvršćene kulama s uglavnom četiri ulaza. Unutar logora najviše su mjesta zauzimale vojničke spavaonice (contuberniae). U središtu se nalazila zgrada zapovjedništva (principia), stan zapovjednika (praetorium), skladište za žito (horreum), radionice (fabrica). U većim logorima postojala je bolnica (valetudinarium). Kupališta su bila smještena uglavnom izvan zidina logora. Unutar logora postojao je sustav za dovod vode, kao i kanalizacija. Vidi: Bishop 2012 i njegovu internetsku stranicu: http://www.legionaryfortresses.info/ index.htm (24. 10. 2019).

3 Dalje prema istoku, najplodnije područje Dalmacije u antičko vrijeme kao i danas, smješteno je i oko rijeke Neretve (Naro flumen), a pogotovo oko njenoga ušća. Vidi: Pejnović 2002: 301-335. tant positions. Those are the legionary fortress Burnum, located in the vicinity of modern-day Ivoševci, above the River Krka (Titius flumen), and Tilurium, located in the modern-day village of Gardun, above the River Cetina (Hyppus flumen). ${ }^{2}$

In the karst geomorphology of the wider area of Burnum and Tilurium, it is possible to distinguish three different landscapes. Those are (1) the islands, whose direction follows the direction of the mountains on the mainland, due to which they belong to the continental type, (2) the elongated, narrow coastline and (3) the hillsides in the interior which border the mountain ranges of Velebit, Dinara, and Kamešnica (Radić Rossi 2017: 549-576). The rivers that flow into the Adriatic Sea have made parts of land around them, as well as their mouths, very fertile. In the area that interests us here, rivers Krka and Cetina stand out. Their fertile surroundings include the plains of Ravni Kotari in the hinterland of lader and Sinjsko polje, a valley in the hinterland of Salona. ${ }^{3}$ Along with making their environment fertile, these rivers also represented natural obstacles for land travel. The importance of travel routes was noted in the earliest times so it was clear to the Romans that these two rivers were a communication of great importance both for the commodity and the flow of people.

Following consolidation and strategic positioning, the Romans quickly began connecting the newly occupied area by planned road construction, the topography of which was influenced by its geomorphological structure. The state road Aquileia - Dyrrhachium, connecting the west and east of the Empire, and which is protected along the eastern side of the Adriatic coast, could not pass the shortest route along the coast. The reason for this are the foothills of mountain massifs, which reached the very sea. Therefore, the roads went along their northern side where passage was easier. This state road communicated with settlements on the coast by numerous side roads going through mountain passes (Bojanovski 1974; Miletić 1993: 117-150; 2006: 125-136). When laying down certain routes, the Romans used the already existing communications of the local population, since these pre-Roman routes, not only in the province of Dalmatia but also in other parts of the Empire, were mostly the best solution. It turned out that communications used by the native population were based on experience gained through many centuries, and mostly represented the safest and fastest routes.

The main road Aquileia - Dyrrhachium and its section

2 The earliest description of a Roman military camp was preserved in the writings of the Greek historian Polybius $(V I, 39)$ from the $2^{\text {nd }}$ cent. BC. He described a movable camp of rectangular shape, protected by a ditch and a parapet, where soldiers slept in tents made of skin. Hyginus (De mun. castr. 16) devoted his work to the research of the camp's architecture, and recommended that the ratio of the length to the width of the camp should be 1:3. The first permanent camps were built of wood, but since the middle of the $1^{\text {st }}$ cent. AD they began to be built, at least partially, from stone. Their ground plans were mostly the same, but differed in size. Smaller ones were occupied by auxiliary units and larger ones by legionary units. All camps had walls fixed with towers with four entrances. Most space within the camp was occupied by military dormitories (contuberniae). In the center stood the headquarters ( principia), the commander's residence (praetorium), granary (horreum) and workshops (fabrica). The larger camps also had a hospital building (valetudinarium). Baths were mainly located outside the walls. Also, within the camp, there existed a water supply and a sewage system. See: Bishop 2012 and his website: http:// www.legionaryfortresses.info/index.htm (24 October 2019).

3 The most fertile area of Dalmatia, in ancient times as well as today, was located around the river Neretva (Naro flumen), which is located further to the east, and especially around its mouth. See: Pejnović 2002: 301-335. 
komunikacije domaćega stanovništva postavljene na temeljima iskustva sakupljenoga kroz mnoga stoljeća, uglavnom najsigurnije i najbrže. that lay between Burnum and Tilurium were recorded on antique maps (Tabula Peutingeriana: Burno XVI Promona VIII Magno XIIII Andetrio XIV Salona; Anonymus Ravennas (IV, 16):

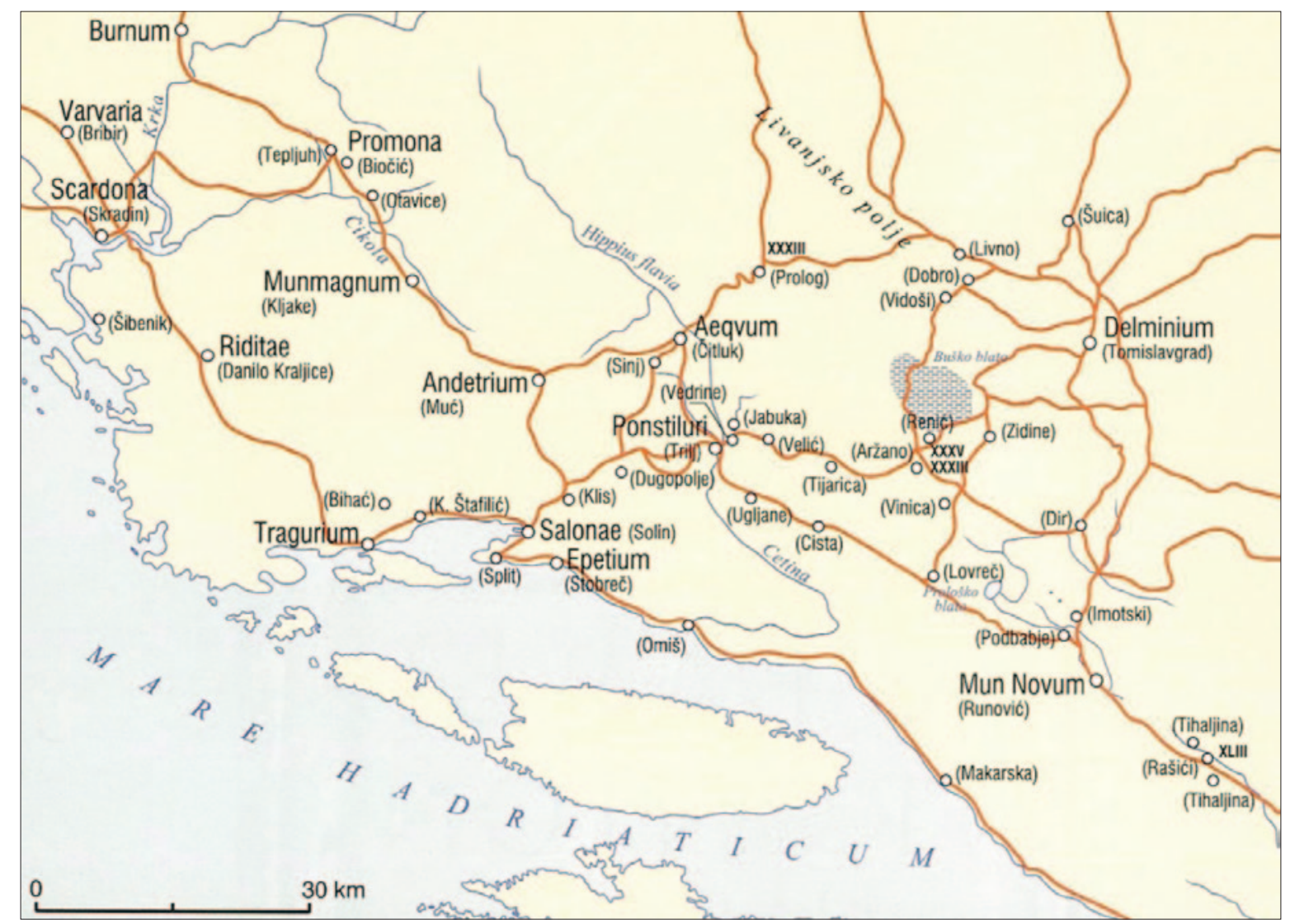

Karta 1 Lokaliteti i prometnice u zaleđu Salone (prema: Zaninović 2015: 456)

Map 1 Sites and road communications in the hinterland of Salona (after: Zaninović 2015: 456)

Magistralna cesta Aquileia - Dyrrhachium, pa tako i njena dionica između Burna i Tilurija zabilježena je na antičkim kartama (Tabula Peutingeriana: Burno XVI Promona VIII Magno XIIII Andetrio XIV Salona; Anonim iz Ravene (IV, 16): Promona - Magnum - Endetrium) i potvrđena nalazima miljokaza kod Otavica i Uzdolja (Kolb, Walser 2007: 140, 161). $\mathrm{Na}$ izgradnju pojedinih dionica ceste ukazuju i epigrafski spomenici (CIL 03, 3198a = 10156a; CIL 03, 3200; CIL 03, 2908). Sporedna cesta koja iz legijskoga logora Burna vodi na istok spaja se $s$ magistralnom cestom prije prijelaza preko rijeke Krke na Bobodolu. ${ }^{4}$ Nakon što prijeđe Krku, cesta nastavlja preko zaseoka Marasovine u smjeru Uzdolja. ${ }^{5}$ Nakon Uzdolja skreće južno u smjeru Promone. Iz Promone cesta dalje nastavlja prema Kadinoj Glavici koju zaobilazi sa sjeveroistoka te se nastavlja rubom Petrovoga polja. ${ }^{6}$

4 U mjestu Žeželji utvrđena je bifurkacija (bivum) ove ceste gdje se jedan njen krak odvaja za Burnum (Vidi: Kolb, Walser 2007: 139, br. 4,239). Riječni prijelaz koji nosi ime Bobodol (kao i jedno selo u blizini) neki zovu i Ćavlina buk. Danas se na mjestu prijelaza s njegove lijeve i desne strane nalaze sela Marasovine, odnosno Radučić. Na mjestu prijelaza vršena su stalna prokopavanja slapa, pri čemu su pronalaženi i pokretni arheološki nalazi (CIL 03, 2826; CIL 03, 2827). Vidi i Fortis 1984: 77.

5 Na prostoru sela Bobodol, na položaju Gaj, ta se cesta može više stotina metara pratiti kao usječena tlaka. Vidi Glavaš 2015: 130.

6 Ta je rimska cesta još vidljiva u okolici Otavica i to iznad zaseokā Meštrovića i Reljanovića odakle se pruža prema zaseoku Gabrića. Usp. Glavaš 2015: 132.
Promona - Magnum - Endetrium) and confirmed by milestones found in Otavice and Uzdolje (Kolb, Walser 2007: 140, 161). The inscriptions on several epigraphic monuments also witness to the construction of individual sections (CIL 03, 3198a = 10156a; CIL 03, 3200; CIL 03, 2908). A side road leading from the legionary fortress Burnum to the east connects to the main road before crossing the river Krka to Bobodol. ${ }^{4}$ After crossing Krka, the road continues through the hamlet of Marasovine in the direction of Uzdolje. ${ }^{5}$ After Uzdolje it turns south in the direction of Promona. From Promona, the road continues towards Kadina Glavica, which the road bypasses on the northeast and continues further along the edge of a valley called Petrovo polje. ${ }^{6}$ The road continues further south-east and passes through Gradac to cross the river Čikola (near the former Vezović bridge). From here it enters Balina glavica (Magnum?) and continues

4 A bifurcation (bivum) of this road is located in the village of Žeželji, where one of its parts separates towards Burnum (see: Kolb, Walser 2007: 139, Nr. 4,239). The river crossing bearing the name Bobodol (the same as a nearby village) some also call Čavlina buk. Today, at the crossing's location are villages of Marasovine and Radučić. At this location, during continuous waterfall dig work, several archaeological finds were uncovered (CIL 03, 2826; CIL 03, 2827). See also: Fortis 1984: 77.

5 In the area of the village of Bobodol, on the location Gaj, this road can be followed by ruts for several hundred meters. See: Glavaš 2015: 130.

6 This Roman road is still visible in the vicinity of Otavice, above the hamlets of Meštrović and Reljanović, from where it stretches towards the hamlet of Gabrić. Compare: Glavaš 2015: 132. 
Cesta se nastavlja dalje jugoistočno i prolazi kroz Gradac da bi prešla preko rijeke Čikole (kod nekadašnjega Vezovića mosta). Odatle ulazi u prostor Baline glavice (Magnum?) i dalje prema Muću (Andetrium). Ta je dionica ceste Aquileia - Dyrrhachium vodila od Baline Glavice jedinim mogućim pravcem koji pak slijedi kanjon rijeke Vrbe od Kljaka, preko Donjeg i Gornjeg Postinja u smjeru Donjeg i Gornjeg Muća (Miletić 1993: 134-136; Glavaš 2015: 133-134).

lako na antičkim kartama nije zabilježeno, vjerujemo da magistralna longitudinalna prometnica za Dyrrhachium nije nakon Andetrija skretala prema Saloni, već je najkraćim putem nastavljala prema prijelazu na rijeci Cetini. ${ }^{7}$ Ako je i skretala na jug prema Saloni, nije trebala ulaziti u grad, nego na bifurkaciji u Dugopolju skrenuti na istok i priključiti magistralnoj cesti Salona - Argentaria. Ako je nastavljala od Andetrija najbržim pravcem prema Cetini, nije sigurno koji bi to pravac bio. U literaturi se predlaže pravac koji vodi preko Neorića, prijevojem ispod Imbera, dalje prema Sičanima i podno Velike Mojanke prema Turjačkim podima, Vojniću i Tiluriju. ${ }^{8}$ Na nju se negdje (Vojnić ?) mogla priključiti i spomenuta magistralna cesta Salona - Argentaria. ${ }^{9}$

\section{SUKOB}

Složeni vojno-politički događaji koji su se odvili na istočnoj obali Jadrana započeli su u razdoblju između 1. i 2. punskoga rata (Polyb. II, 9-10) u 229. god. pr. Kr. te su se nastavili s kraćim ili duljim prekidima do 9. god. (Vell. Pat. 2, 110-122; Cass. Dio. 55. 29-34, 56. 11-26). Nakon uspjeha u Prvome punskom ratu, Rimljani su se zainteresirali za područje Grčke i Makedonije do kojega su mogli morem ili jedinom kopnenom komunikacijom koja je prolazila duž istočne obale Jadrana teritorijem neprijateljskih Ilira. ${ }^{10}$ Rimska mornarica se uspješno sukobila s brodovljem Ilirskoga kraljevstva kojim je u to vrijeme vladao narod Ardijejaca. Kako Rimljanima ovo osvojeno područje nije bilo dostatno, deset godina kasnije poslali su brodove kako bi ponovno zaratili s Ilirima

7 Jedan od nekoliko prijelaza preko Cetine bio je smješten u blizini, odnosno podno logora Tilurium. U stručnoj literaturi spominje se postojanje dva, pa čak i tri mosta koja su u antici služila za prijelaz preko rijeke Cetine (Miletić 2006: 131; Glavaš 2015: 135-136). O prijelazima preko rijeke Cetine vidi razmišljanja N. Cesarika (2018: 53-63). O 1849. godine pronađenom natpisu (CIL 03, 3202), datiranom u 184. god., a koji svjedoči o obnovi jednog mosta vidi: Gunjača 1949: 50-52.

8 F. Bulić je 1903. godine pisao o jednom segmentu te trase koji je još bio vidljiv od crkve sv. Jurja u Vojniću prema Mojanki (Bulić 1903: 121-122). Šezdesetih godina 20. st. je J. Britvić u pokušaju rekognosciranja te trase vidio spurile u klancu podno brda Imber, u Sičanima i kod zaseoka Kokani koje je smješteno podno brda Velika Mojanka (Britvić 1971: 29 i bilj. 2). Kasnije je taj isti pravac ispitivao i L. Bekić koji je, kako piše, vidio spurile na Turjačkim podima (Bekić 2002: 130-131). S J. Britvićem i L. Bekićem slažu se I. Glavaš i Ž. Miletić (Miletić 2006: Map 5; Glavaš 2015: 135).

9 I. Glavaš se slaže s Bulićevim prijedlogom da se cesta, nakon bifurkacije u Dugopolju, proteže prema Gardunu prolazeći Vučipolje ispod brda Bubovača i dalje preko Prosika, odakle se nastavlja prema Bisku, da bi se preko Samoleča spustila u dolinu Vojnića jugozapadno od logora Tilurium (Glavaš 2015: 163).

10 To je područje, nastanjeno narodima koje su Rimljani nazivali Ilirima (Illyrii), obuhvaćalo teritorij koji se protezao od Jadranskoga mora sve do rijeka Save (Savus flumen), Drave (Dravus flumen) i Drine (Drinus flumen). Vidi: Cabanes 1983: 187-204; 1988. towards Muć (Andetrium). This section of the Aquileia - Dyrrhachium road led the only possible direction from Balina glavica, following the canyon of the river Vrba from Kljake, through Gornje Postinje and Donje Postinje, and in the direction of Donji Muć and Gornji Muć (Miletić 1993: 134-136; Glavaš 2015: 133-134).

Although not recorded on antique maps, we believe that the main longitudinal road for Dyrrhachium did not turn towards Salona after going through Andetrium, but followed the shortest route to cross the river Cetina. ${ }^{7}$ Even if it did go south towards Salona, it did not need to enter the city but could have turned east at the bifurcation in Dugopolje and joined the main road Salona-Argentaria. If it did indeed follow the fastest route from Andetrium to Cetina, it is not clear which exact route it would be. Literature suggests a course that runs through Neorić, passes below Imber, further runs to Sičani and below Velika Mojanka towards Turjački podi, then Vojnić and Tilurium. ${ }^{8}$ Somewhere along, the nearby main road Salona - Argentaria could have been connected to it (Vojnić?). ${ }^{9}$

\section{CONFLICT}

The complex string of political and military events that took place on the eastern Adriatic coast began in the period between the $1^{\text {st }}$ and $2^{\text {nd }}$ Punic Wars in 229 BC (Polyb. II, 9-10) and continued with shorter or longer interruptions until 9 AD (Vell. Pat. 2, 110-122; Cass. Dio. 55. 29-34, 56. 1126). Following their success in the $1^{\text {st }}$ Punic War, the Romans became more interested in the area of Greece and Macedonia, which they could access either by sea or by a land route stretching along the eastern Adriatic coast through the hostile Illyrian territory..$^{10}$ The Roman navy successfully clashed with the Illyrian fleet, whose kingdom was at that point ruled by the Ardiaei people. As the conquered area was not sufficient, the Romans sent ships to fight the Illyrians again ten years later (Liv. 45, 26). ${ }^{11}$ In the wars that followed, Macedonia fell into Roman hands at the same time

7 One of several crossings over the Cetina River was located bellow the legionary fortress Tilurium. In the scientific literature, researchers mention the existence of two or even three bridges used in the ancient times to cross the Cetina River (Miletić 2006: 131; Glavaš 2015: 135-136). About the crossings over the river Cetina see the thoughts of N. Cesarik (2018: 53-63). About the inscription (CIL 03, 3202), found in 1849 and dated to $184 \mathrm{AD}$, which testifies to the reconstruction of a bridge, see: Gunjača 1949: 50-52.

8 In 1903, F. Bulić wrote about one part of this road that was still visible near the church of St. Juraj in Vojnić towards Mojanka (Bulić 1903: 121-122). In the 1960 's, in the attempt to locate the course, J. Britvić spotted ruts in a col bellow the hill Imber, in Sičane and at the hamlet Kokani, located bellow the hill of Velika Mojanka (Britvić 1971: 29 and note 2). The same route was later researched by L. Bekić who, as he wrote, saw ruts at Turjački podi (Bekić 2002: 130-131). I. Glavaš and Ž. Miletić agree with the observations of J. Britvić and L. Bekić (Miletić 2006: Map 5; Glavaš 2015: 135).

9 I. Glavaš agrees with Bulić's suggestion that the road after the bifurcation in Dugopolje stretches towards Gardun, passing Vučipolje beneath the hill of Bubovača and further through Prosika, from where it continues to Biska to go down to Vojnić valley, southwest of the legionary fortress Tilurium (Glavaš 2015: 163).

10 This area, inhabited by the people whom the Romans called Illyrians (Illyrii), included the territory stretching from the Adriatic Sea to the rivers Sava (Savus flumen), Drava (Dravus flumen) and Drina (Drinus flumen). See: Cabanes 1983: 187-204; 1988.

11 The recent book of M. Zaninović Ilirski ratovi lists all the relevant literature: Zaninović 2015. 
(Liv. 45, 26). ${ }^{11}$ U ratovima koji su uslijedili, Makedonija je pala u rimske ruke $u$ isto vrijeme kao i llirsko kraljevstvo Ardijejaca. Kako su Rimljani već pobijedili u ratu protiv Histra (179. - 178. god. pr. Kr.) (Liv. 41, 11), koji su nastanili najzapadniji dio istočnoga Jadrana, tako su zavladali Istarskim poluotokom, stekavši time nadzor nad istočnim jadranskim otocima i uskim obalnim pojasom koji im je omogućio kopneni put prema Makedoniji. Novoosvojeni teritorij omogućio je naseljavanje rimskih građana, iskorištavanje prirodnih resursa te trgovinu što je sve imalo blagotvorni utjecaj na gospodarstvo Carstva. Rimljani, međutim, još nisu uspjeli prodrijeti u zaleđe istočne obale Jadrana i dalje prema Dunavu što je predstavljalo stalnu prijetnju naseljima rimskih građana na obali i otocima. Stoga su sljedećih nekoliko desetljeća ratovali s ilirskim narodima u unutrašnjosti, među kojima su se isticali Delmati, Japodi i panonski narodi. Taj je problem, u ratovima od 35. do 33. god. pr. Kr., djelomično riješio Oktavijan koji je osvojio neke otoke i dio unutrašnjosti llirika (Schmitthenner 1958: 189-236; Wilkes 1969: 46-55; Coppola 1999: 195-212). Osvajanje unutrašnjosti nastavio je Tiberije za vrijeme Panonskoga rata (12. - 11. god. pr. Kr.), međutim, potpuna kontrola llirika nastupila je tek nakon suzbijanja Delmatsko-panonskog ustanka 6. - 9. god. (Aur. Vict. Caes. 1; Cass. Dio. 55. 29-34, 56. 11-26; Oros. VI, 21; Suet. Tib. 9; Vell. Pat. Hist. II, 96, 110-122). ${ }^{12}$

Do toga ustanka došlo je nakon što je za potrebe ratovanja u Germaniji Augustov vojskovođa Tiberije pokušao u Iliriku novačiti dodatne kontingente vojnika. Novačenje nije dobro odjeknulo među domaćim stanovništvom, pa su se već 6. god. pobunili Dezidijati koje je predvodio vođa imenom Baton (Mesihović 2013: 21-136). Ustanku su se uskoro priključili Delmati kao i panonski Breuci pod vodstvom dvojice zapovjednikā od kojih se jedan također zvao Baton i drugoga koji se zvao Pines. Uskoro je u pobuni sudjelovao čitavi llirik od Dunava i Drave do mora kojim su se priključili i oni lliri koji su već bili pripadnici pomoćnih četa. ${ }^{13} \mathrm{U}$ pohodu prema moru, odnosno prema Saloni, Dezidijati su opustošili čitavo jadransko priobalje. Izgleda da je Baton Desitijat tom prilikom i ranjen što ih nije spriječilo da krenu prema Italiji. U tome su pohodu bili zaustavljeni kao što su bili zaustavljeni i Breuci u pohodu na Sirmij. Tiberije je, sklopivši mir s Germanom Marobodom, stigao u Sisciju gdje je zapovijedao vojskom od 100.000 pješaka i konjanika. U pomoć mu je stigao i Germanik, kao i vojskovođe Antonije Cecin Sever i Plaucije Silvan. U močvarama oko rijeke Vuke Rimljani su porazili oba Batona, kao što je i Germanik porazio Mezeje. Nakon toga su se ustanici počeli raspadati. Breučki je Baton, nagovoren od Rimljana i ohrabren njihovim obećanjima, predao svoga vođu Pinesa, a nakon što je nagovorio Breuke da polože oružje. Za nagradu su mu Rimljani dopustili da

11 Vidi recentnu monografiju M. Zaninovića Ilirski ratovi u kojem jer navedena i sva relevantna literatura: Zaninović 2015.

12 Za ovaj je rat, čija se završnica odigrala na istočnoj obali Jadrana, Svetonije (Tib. 16.1) napisao da je jedan od najtežih rimskih ratova te ga naziva kako smo rekli u uvodu: gravissimum omnium externorum bellorum post Punica. Vidi i trendovske narative o ustanku: Džino 2009: 29-45.

13 Velej Paterkul (Vell. Pat. Hist. II, 110-122) suvremenik događaja, bilježi da je bilo oko 800.000 ustanika od kojih su 200.000 vojnici pješaci, a 9000 konjanici. as the Illyrian Ardiaei kingdom. Since the Romans already won the war against the Histri people in $179-178$ BC (Liv. $41,11)$, who lived on the westernmost part of the eastern Adriatic, they ruled the Istrian peninsula, which means they gained control over the eastern Adriatic islands and narrow coastal strip that ensured the overland route to Macedonia. Newly conquered territory enabled the settling of Roman citizens, the exploitation of natural resources and trade, all of which had a beneficial impact on the economy of the Empire. The Romans, however, had not yet succeeded in penetrating further into the hinterland of the eastern Adriatic coast towards the Danube, which presented a constant threat to Roman settlements along the coast and on the island. Therefore, the next several decades they waged war with other Illyrian peoples from the interior, among which stood out the Delmatae, lapodes and the Pannonian peoples. This problem was partially addressed by Octavian, who conquered several islands and parts of the interior of the Illyricum in the wars from 35 to 33 BC (Schmitthenner 1958: 189-236; Wilkes 1969: 46-55; Coppola 1999: 195-212). Further conquest in the Illyricum interior was done by $\mathrm{Ti}$ berius during the Pannonian war (12 - $11 \mathrm{BC})$, but complete control was established only after suppressing the Delmataean-Pannonian rebellion in 6 - 9 AD (Aur. Vict. Caes. 1; Cass. Dio. 55. 29-34, 56. 11-26; Oros. VI, 21; Suet. Tib. 9; Vell. Pat. Hist. II, 96, 110-122)..$^{12}$

This uprising occurred after Tiberius, as a general under Augustus, attempted to muster additional troops from Illyricum to support the war in Germania. The additional muster, not well received among the local population, sparked a rebellion of the Daesitiate people in 6 AD led by a leader named Bato (Mesihović 2013: 21-136). The Delmatae soon joined the uprising, as well as the Pannonian Breuci, under the leadership of two commanders, one of whom was also called Bato and the other called Pines. Soon the entire Illyricum was in rebellion, from the Danube and the Drava rivers to the sea, and was even joined by the Illyrians serving in the auxiliary units. ${ }^{13}$ On their way to the sea, i.e. towards Salona, the Desidiates ravaged through the entire Adriatic coast. During this, it seems that Bato of the Desidiate people was wounded, which did not prevent them from going towards Italy. Their march was eventually stopped, as was the one Breuces conducted towards Sirmium. Following a truce with Maroboduus in Germania, Tiberius had arrived in Siscia, where he held under his command an army consisting of 100.000 infantry and horsemen. Supporting him was also Germanicus, as well as generals A. Caecina Severus and $M$. Plautius Silvanus. In the swamps around the river Vuka, the Romans defeated both Batos, and Germanicus defeated the Maezaei people. After that, the uprisings began to collapse. Bato of the Breuci people, persuaded by the Romans and encouraged by their promises, surrendered his leader Pines. As a reward, the Romans allowed him to become the leader of the Breuci tribe. However, Bato of the Desidiate people was

12 This rebellion, one of the most difficult of Roman wars, whose final stage took place on the eastern Adriatic coast, was described as such by Suetonius (Tib. 16.1), who called it gravissimum omnium externorum bellorum post Punica. Also see postmodern narratives on the rebellion: Džino 2009: 29-45.

13 Velleius Paterculus (Vell. Pat. Hist. II, 110-122), a contemporary of these events, notes that there were about 800.000 rebels of which 200.000 infantry and 9.000 horsemen. 
postane vođom Breuka. Desitijatski Breuk bio je izgleda čovjek drugačijega kova. Kada je doznao za izdaju breučkoga Batona, otišao ga je kazniti te ga je zarobio i pogubio. Nakon toga se vratio u Dalmaciju ne posustajući u borbi protiv Rimljana. ${ }^{14}$ Rat protiv pobunjenika je 8 . god. vodio Germanik. On je osvojio Splonum, međutim, bio je poražen kod Rhetinija, zbog čega se u borbu vratio i Tiberije. Završnica sukoba zbila se u Andetriju gdje se utaborio Baton. Bio je to početak kraja krvavoga sukoba u kojem je Tiberije na prevaru zauzeo Andetrij otkrivši tajnu stazu iz utvrde. Međutim, Tiberije je ipak pomilovao Batona poslavši ga u Ravenu gdje je ovaj i umro. ${ }^{15}$

\section{MIR}

Nakon završetka građanskih ratova dao je Oktavijan 12. siječnja 29. god. pr. Kr. zatvoriti vrata Janova hrama na rimskome forumu (Sanader 2015). Tim postupkom započinje nova era, era u kojoj je pala Republika, a utemeljen principat. Era koja se kadikad naziva i augustovskom, a koju karakterizira unutarnja i vanjska stabilizacija Carstva (Torelli 1988: 23-48). Ona je mogla biti postignuta uz pomoć uspostave sigurnosti i vladavine prava koji su potom omogućili gospodarski i kulturni razvoj. August, koji je inzistirao na povratku tradicionalnim vrijednostima kao što su disciplina, red, skromnost, poštenje, pobožnost i moral, daje graditi ceste, akvadukte i mostove, čime je usavršio sustav komunikacija između Rima i provincija (Heilmeyer et al. 1988). U Rimu daje podići čudesne građevine, spomenimo ovom prilikom samo oltar mira, slavni Ara pacis. Međutim, da bi postigao potpuni mir u Carstvu, August je, kao i njegovi nasljednici, uz pomoć goleme vojne sile i njihovih vojskovođa nastavio osvajati teritorije tuđih zemalja dok ga nije zaustavio golemi, iznenađujući i sramotni poraz njegovoga povjerenika Vara u Teutoburškoj šumi (Sanader 2018: 16-23). August je isto tako uredio državnu upravu čime je do izražaja došla ideja da se mir i prosperitet koji je provincijama nudio Rim mogao postići isključivo uz pomoć bezrezervnoga i nesmiljenog čuvanja države i društvenoga poretka. Ta kontradiktorna situacija u kojoj su Rimljani s jedne strane propagirali mir, a s druge strane žestoko i nasilno ratovali, bila je predmetom brojnih rasprava od kojih ovom prilikom izdvajamo onu G. Woolfa (1993: 171) koji smatra da "Roman peace may be seen as simply a component of wider patterns of violence, a concomitant of other structures of domination".

U Iliriku se Pax Romana, odnosno istinsko razdoblje mira, moglo ostvariti tek nakon 9. god. Rimljani su tek tada brutalno ugušili delmatsko-panonski ustanak usredotočivši sve svoje snage na smirivanje pobune. Oni koji su se usprotivili Rimu nisu nakon poraza mogli računati ni na milost ni na oprost. Zbog tih događaja uklapanje llirika u Carstvo moglo je biti pokrenuto tek nakon što su za to stvoreni sigurnosni, mirnodopski uvjeti, odnosno Pax Romana. Integracija ovo-

14 Detaljnije o ustanku vidi: Mesihović 2013 i Zaninović 2015.

15 August (Res gestae, 30) je o ovome ustanku napisao: „Panonska plemena do kojih prije mene vojska rimskoga naroda nikada nije stigla, pobijedio sam po Tiberiju Neronu, koji je tada bio moj pastorak i zapovjednik, i podložio vlasti Rimskoga naroda. Pomaknuo sam granice Ilirika na obale rijeke Dunava.“ a man of different principles. When he heard news about the treason, he went to punish Bato of the Breuci, who he then imprisoned and executed. Afterward, he returned to Dalmatia and continued to wage war against the Romans. ${ }^{14}$ Germanicus was leading the war against the rebels in the 8 AD. He occupied Splonum, but was defeated at Rhetini, which made Tiberius return to the battlefield. The conflict came to its end at Andetrium, where Bato settled. It was the beginning of the end to the bloody conflict in which Tiberius occupied Andetrium by revealing a secret path leading to the fort. Nevertheless, Tiberius pardoned Bato by sending him to Ravenna, where he eventually died. ${ }^{15}$

\section{PAX}

After the civil wars have ended, on $12^{\text {th }}$ of January 29 BC, Octavian closed the gate of the Temple of Janus at the Forum Romanum (Sanader 2015). With this act began a new era, the era in which the Republic fell, and the Principate was founded. This era is sometimes called the Augustan era, which is characterized by internal and external stabilization of the Empire (Torelli 1988: 23-48). It was able to achieve this by establishing security and the rule of law, which in turn enabled economic and cultural development. Augustus, who had insisted on returning to traditional values such as discipline, order, humility, honesty, piety, and morality, orders the building of roads, aqueducts, and bridges, thus perfecting the system of communication between Rome and its provinces (Heilmeyer et al. 1988). In Rome, he orders marvelous buildings to be built, such as the altar of peace, the famous Ara pacis. However, in order to achieve complete peace in the Empire, Augustus, much like his heirs, continued to conquer foreign territories with the help of the enormous military force and its generals. This continued until the surprising and disgraceful defeat of Varus in the Teutoburg Forest (Sanader 2018: 16-23). Augustus organized the state administration as well, and thus elevated the idea that peace and prosperity the provinces offered to Rome could be achieved solely by mercilessly preserving the state and social order. This somewhat contradictory situation in which the Romans, on the one hand, propagated peace and on the other hand fiercely and violently fought, was an object to numerous discussions. On this occasion we quote $G$. Woolf (1993: 171) who believes that "Roman peace may be seen as simply a component of wider patterns of violence, a concomitant of other structures of domination".

The Pax Romana, i.e. the true period of peace, could only be realized in Illyricum after 9 AD when the DelmataeanPannonian Rebellion was crushed. The Romans concentrated all their forces to calm the rebellion, and those who opposed Rome couldn't count on mercy and forgiveness after their defeat. The incorporation of Illyricum into the Empire could have only been initiated when security and peaceful conditions were met, i.e. Pax Romana. The integration of this area should have followed the established patterns,

14 For more details on the uprising, see: Mesihović 2013 and Zaninović 2015.

15 Augustus (Res gestae, 30) about this rebellion wrote: "The tribes of the Pannonians, to which no army of the Roman people had ever penetrated before my principate, having been subdued by Tiberius Nero who was then my stepson and my legate, I brought under the sovereignty of the Roman people, and I pushed forward the frontier of Illyricum as far as the bank of the river Danube." 
ga područja trebala je slijediti utvrđene obrasce koji su se primjenjivali i na druge novoosnovane provincije. To znači da je nakon preuzimanja novoga teritorija, zajedno s naseljavanjem rimske populacije, započela i izgradnja trajnih instalacija u kojima je boravila vojska kao što su to legijski logori i kasteli (Johnson 1987; Baatz 1993; Schallmayer 2005; Klose, Nünnerich-Asmus 2006; Planck, Thiel 2009; Breeze, Jilek 2008). Odnos pridošlih rimskih civila i pridošle vojske u provincijama bio je uzajaman i recipročan. Tako i duž istočno jadranske obale gdje je stalna rimska vojna nazočnost olakšala rimsku upravu i izgradnju urbane infrastrukture u novoosnovanim naseljima rimskih imigranata. Nova uprava na osvojenim je područjima uspostavila civilnu infrastrukturu, uvela administraciju i započela urbanizaciju naselja koje je u zaleđu štitila vojska (Ramsay 1941; Campbell 2002: 89-91; Southern 2007: 77-82). Bez nazočnosti vojske, one iste rimske vojske koja se nešto ranije sukobila s domaćim stanovništvom, uspostava mira ne bi bila moguća.

\section{ARHEOLOGIJA RIMSKE VOJNE SILE KAO POKAZATELJ KRAJOLIKA SUKOBA?}

Kako je ranije kazano, u zaleđu Jadera i Salone potvrđena su dva legijska logora (Burnum i Tilurium), a između njih se pretpostavlja i postojanje nekoliko kastela. U znanstvenoj se literaturi ovaj longitudinalni niz vojničkih utvrda naziva ponekad i delmatski limes. ${ }^{16} \mathrm{Da}$ bi dobili što precizniji odgovor o uzroku, svrsi i cilju takvoga vojnog rasporeda, sakupili smo sve raspoložive podatke o teritorijalnoj rasprostranjenosti vojnika i vojnih postrojbi širega područja između legijskih logora Burnum i Tilurium. ${ }^{17}$

Legijski logor Burnum smješten je na lijevoj obali rijeke Krke (Titius) u zaleđu grada Jadera. Ostaci logora, kojega su nakon osvajanja tog područja podigli Rimljani, nalaze se u blizini sela Ivoševci. Sama utvrda bila je strateški smještena na platou strme visoravni poviše rijeke Krke. Taj mu je položaj omogućavao izvanrednu vidljivost okolnih područja. Nakon 86. god. iz Burna odlazi posljednja legija te ga koriste samo pomoćne trupe. Istovremeno s tim događajima razvija se civilno naselje u njegovoj blizini koje je u jednom trenutku steklo i municipalitet. Arheološka istraživanja Burna iznjedrila su na svjetlo dana ne samo tragove nekadašnjega legijskog logora, nego i grada koji se uz njega razvio (Cambi et al. 2007: 27-28). Najranija poznata postrojba u Burnu je legio XX Valeria Victrix (Cambi et al. 2007: 13-15; Miletić 2010: 120; Glavaš 2015: 20; Cesarik 2019: 1-12). Kako navodi Velej Paterkul (Hist. II, 112), dvadeseta je legija već ranije sudjelovala u borbama u Iliriku. Zasad nam je na prostoru između Burna i Tilurija poznat tek jedan natpis (HD061408), prona-

16 Zanimanje za tu temu iznjedrilo je više znanstvenih rasprava koje do danas nisu ponudile zadovoljavajuće rješenje. Usp. Šašel 1974: 194-199; Wilkes 1977: 245-246; Šašel 1992: 397-403; Sanader 2002: 713-718; Periša 2008: 507-517.

17 Prilikom sakupljanja vojničkih natpisa služili smo se internetskom bazom Epigraphische Datenbank Heidelberg koja navodi i osnovnu literaturu o spomenicima. Iz ove rasprave izostavljeni su pečati vojnih postrojbi s toga područja. Razlog tome je što je danas opće prihvaćeno mišljenje da pečati na tegulama ne moraju nužno ukazivati na lokalnu prisutnost vojničke trupe koja se spominje na pečatu. Vidi: Tončinić 2009: 1447-1459; Tončinić et al. 2011: 364-365. which were applied to other newly established provinces. This means that after taking over new territory, along with settling of Roman population, began also the construction of permanent installations in which the army was staying, such as legionary fortresses and auxiliary forts (Johnson 1987; Baatz 1993; Schallmayer 2005; Klose, Nünnerich-Asmus 2006; Planck, Thiel 2009; Breeze, Jilek 2008). The relationship between Roman civilians and the military in the provinces was mutual and reciprocal. So it was along the eastern Adriatic coast where constant Roman military presence facilitated Roman administration and the construction of urban infrastructure in newly established settlements of Roman immigrants. The new administration has established civilian infrastructure in the conquered territories, introduced administration and started urbanization of the settlement, which was defended by the army in the hinterland (Ramsay 1941; Campbell 2002: 89-91; Southern 2007: 77-82). Without the presence of the Roman army, the same army that had previously clashed with the domestic population, establishing peace would not be possible.

\section{THE ARCHAEOLOGY OF ROMAN MILITARY FORCE AS INDICATOR OF A LANDSCAPE OF CONFLICTS?}

As previously stated, in the hinterland of lader and Salona, two legionary fortresses (Burnum and Tilurium) are attested and several forts between them are assumed. In scientific literature, this longitudinal defensive system of forts is sometimes referred to as the Delmataean limes. ${ }^{16}$ In order to obtain a more precise answer to the cause, purpose, and aim of such defensive system, we have gathered all available information on the territorial distribution of soldiers and military units on the wider area between the legionary fortresses Burnum and Tilurium. ${ }^{17}$

The legionary fortress Burnum is located in the hinterland of lader, on the left bank of the river Krka (Titius). The remains of the fortress, which was raised by the Romans after conquering the area, are located near the modern-day village of Ivoševci. The fortress itself was located on a plateau rising sharply above the river. The position enabled excellent visibility and a complete overview of the surrounding area. The last legion left Burnum in $86 \mathrm{AD}$, at which point it started to be used solely by smaller military units. A civil settlement developed in its proximity and even attained the rank of municipium. Archaeological research in Burnum discovered not only traces of the legionary fortress but also of the town that developed from it (Cambi et al. 2007: 27-28). It is thought that the first military unit garrisoned in Burnum was legio XX Valeria Victrix (Cambi et al. 2007: 13-15; Miletić 2010: 120; Glavaš 2015: 20; Cesarik 2019: 1-12). The twentieth legion, as was mentioned by Marcus Velleius Paterculus (Hist. II, 112), had already previously fought in Illyri-

16 Interest in this topic resulted in several scientific discussions that have not yet offered a satisfactory solution. Compare: Šašel 1974: 194-199; Wilkes 1977: 245-246; Šašel 1992: 397-403; Sanader 2002: 713-718; Periša 2008: 507-517.

17 When collecting military inscriptions, we used online database Epigraphische Datenbank Heidelberg, which also cites basic literature on monuments. Production stamps of military units originating from this area are left out of this research. The reason for this is that today's generally accepted opinion is that the stamping on the tiles does not necessarily point to the local presence of the military unit mentioned on the stamp. See: Tončinić 2009: 1447-1459; Tončinić et al. 2011: 364-365. 
đen u Burnu, koji spominje tu legiju. Pretpostavlja se da je ova legija, nakon gušenja ustanka 9. god., premještena izvan provincije (Cambi et al. 2007: 14; Glavaš 2015: 20-21). Tacit (Ann. I, 39.) spominje dvadesetu legiju u logoru u Germaniji nedugo nakon. Nakon njenoga odlaska, u Burn dolazi legio XI (od 42. god. poznata pod nazivom legio XI Claudia pia fidelis) (Zaninović 1996a: 214; Cambi et al. 2007: 16-17; Miletić 2010: 120-123; Glavaš 2015: 22). U Burnu je do sada pronađeno 30 epigrafskih spomenika pripadnika legio XI. ${ }^{18}$ Legio XI napušta provinciju, kako se smatra, oko 69. god., a zamijenit će je legio IIII Flavia Felix (Wilkes 1969: 103; Zaninović 1996b: 274; Cambi et al. 2007: 18; Miletić 2010: 126). Četvrta legija ostaje u logoru vjerojatno do 86. god. (Wilkes 1969: 97, bilj. 2; Cambi et al. 2007: 18; Miletić 2010: 126; Glavaš 2015: 24). U Burnu su nam se sačuvala tek dva natpisa pripadnika ove postrojbe (HD039874; HD061336). Iz Burna potječe i natpis pripadnika legio VIII Augusta (HD035401). Detalji o boravku ove postrojbe u provinciji Dalmaciji još uvijek nisu razjašnjeni. ${ }^{19}$ Uz njih, postoji i jedan spomenik legio VII (HD061333). U Burnu su tijekom 1. st. bile stacionirane i pomoćne postrojbe o čemu svjedoče epigrafski spomenici koje ćemo ovom prilikom iznijeti kronološki prema mišljenjima iz literature. ${ }^{20}$ Jedna od njih je ala I Hispanorum koja je na području Burna spomenuta tek na jednome spomeniku (HD011485). Točno vrijeme njenoga boravka u Dalmaciji još uvijek je predmet rasprave. ${ }^{21}$ Nađena su i tri spomenika pripadnika cohors II Cyrrhestarum (HD025912; HD034391; HD065347). Čini se da je barem jedno odjeljenje ove postrojbe prisutno u logoru u Burnu, dok su spomenici prisutni i na području legijskoga logora Tilurija (Cambi 1994: 171-174; Cambi et al. 2007: 29-30; Matijević 2009b: 35-43; Miletić 2010: 130-131, 134; Glavaš 2015: 46). O dolasku, duljini boravka i smještaju ove kohorte u Dalmaciji također su iznesena oprečna stajališta, ali čini se vjerojatnim da više nije prisutna nakon flavijevskoga razdoblja. ${ }^{22} \mathrm{U}$ Burnu je boravila i cohors I Montanorum, s čijega prostora potječu dva spomenika ove postrojbe (HD034390; HD035403). Oko dolaska i odlaska ove kohorte iz provincije se stručnjaci isto tako nisu usuglasili, ali bi širi okvir za oba bio druga polovica 1. st. (Cambi et al. 2007: 31-32; Miletić 2010: 132, 134; Glavaš 2015: 51-56).

18 Popis spomenika: HD004410; HD025909; HD028011; HD028171; HD028174; HD031512; HD031659; HD034385; HD034386; HD034387; HD034388; HD034389; HD035392; HD035397; HD039871; HD039872; HD039870; HD055081; HD058137; HD058165; HD058166; HD058168; HD058294; HD058296; HD058298; HD061350; HD061352; HD061355; HD061407; HD061473. Iako se spomenici HD035391 i HD039873 pripisuju pripadnicima jedanaeste legije, to se sa potpunom sigurnošću, zbog necjelovitosti natpisa, ne može utvrditi.

19 Za različita mišljenja o vremenu boravka ove legije u provinciji Dalmaciji vidi: Wilkes 1969: 116; Alföldy 1989: 201-203; Bojanovski 1990: 700, 704, 706-707; Miletić 2010: 127-129; 2011: 270-273; Glavaš 2015: 26-27.

20 Cambi et al. 2007: 7-32; Miletić 2010: 113-134; Glavaš 2015: 61.

21 Može se ustanoviti da je to vrijeme bilo kratko i da se tijekom druge polovice stoljeća više ne nalazi u provinciji. Vidi: Cambi et al. 2007: 26; Miletić 2010: 130; Glavaš 2015: 34.

22 Za različita mišljenja o vremenu boravka ove kohorte u Dalmaciji vidi: Alföldy 1987: 251; Cambi 1994: 171-172; Cambi et al. 2007: 29-30; Miletić 2010: 130-131, 134; Glavaš 2015: 46-49. cum. For now, there is only one tombstone (HD061408) in the area between Burnum and Tilurium, found in Burnum, that mentions the legion. It is assumed that it left the province following the end of the rebellion in $9 \mathrm{AD}$ (Cambi et al. 2007: 14; Glavaš 2015: 20-21) and is shortly after mentioned by Tacitus (Ann. I, 39) as being garrisoned in Germania. Its departure was followed by the arrival of legio XI (known as legio XI Claudia pia fidelis since $42 \mathrm{AD}$ ) and transformation of the seasonal camp into a permanent legionary fortress (Zaninović 1996a: 214; Cambi et al. 2007: 16-17; Miletić 2010: 120-123; Glavaš 2015: 22). So far, 30 epigraphic monuments mentioning members of the legio $X I$ have been found in Burnum. ${ }^{18}$ The legion stayed there until cca. 69 AD, when it was replaced by the legio IIII Flavia Felix (Wilkes 1969: 103; Zaninović 1996b: 274; Cambi et al. 2007: 18; Miletić 2010: 126). Fourth legion remained in the fortress probably until $86 \mathrm{AD}$ (Wilkes 1969: 97, note 2; Cambi et al. 2007: 18; Miletić 2010: 126; Glavaš 2015: 24). Only two inscriptions mentioning this legion have been found in Burnum (HD039874; HD061336). Details of the stay of this unit in the province of Dalmatia are still not clear. ${ }^{19}$ The inscription of a member of the legio VIII Augusta has also been found in Burnum (HD035401). Along with these, a monument mentioning legio $\mathrm{VII}$ is also present (HD061333). According to epigraphic monuments, which we will present on this occasion chronologically according to literature, there were several auxiliary units present in Burnum in the $1^{\text {st }}$ cent. ${ }^{20}$ One of them was ala I Hispanorum, which was on the territory of Burnum mentioned on only one monument (HD011485). The exact time of its stay in Dalmatia is still a debated issue. ${ }^{21}$ Three monuments of the members of the cohors / Cyrrhestarum have also been found in Burnum (HD025912; HD034391; HD065347). It is thought that at least an attachment of this unit was temporarily garrisoned in the auxiliary fort at Burnum, while their monuments are also present in the area of the legionary fortress Tilurium (Cambi 1994: 171-174; Cambi et al. 2007: 29-30; Matijević 2009b: 35-43; Miletić 2010: 130-131, 134; Glavaš 2015: 46). Even though the exact time of its stay in Dalmatia is not agreed upon, it can be stated that it is no longer present in the province after the Flavian period. ${ }^{22}$ Another auxiliary unit stationed in Burnum was the cohors I Montanorum. Two monuments set up by its members originate from Burnum (HD034390; HD035403). It remains unclear at what exact point this cohort arrives and departs the province, but

18 List of monuments: HD004410; HD025909; HD028011; HD028171; HD028174; HD031512; HD031659; HD034385; HD034386; HD034387; HD034388; HD034389; HD035392; HD035397; HD039871; HD039872; HD039870; HD055081; HD058137; HD058165; HD058166; HD058168; HD058294; HD058296; HD058298; HD061350; HD061352; HD061355; HD061407; HD061473. Although monuments HD035391 and HD039873 are attributed to members of the Eleventh Legion, this cannot, due to the incompleteness of the inscription, be determined with certainty.

19 For different opinions on this legion's stay in the province of Dalmatia see and compare: Wilkes 1969: 116; Alföldy 1989: 201-203; Bojanovski 1990: 700, 704, 706-707; Miletić 2010: 127-129; 2011: 270-273; Glavaš 2015: 26-27.

20 Cambi et al. 2007: 7-32; Miletić 2010: 113-134; Glavaš 2015: 61.

21 It can, however, be stated that its stay was most probably short and that it is no longer present in the province in the second half of the century. See: Cambi et al. 2007: 26; Miletić 2010: 130; Glavaš 2015: 34.

22 For different views on its time in Dalmatia see: Alföldy 1987: 251; Cambi 1994: 171-172; Cambi et al. 2007: 29-30; Miletić 2010: 130-131, 134; Glavaš 2015: 46-49. 
Jugoistočno od legijskoga logora Burnum smješteno je Petrovo Polje, plodna ravnica na kojoj se pretpostavljaju antički lokaliteti Promona (Tepljuh) i Magnum (Balina glavica), kao što se pretpostavlja i vojna utvrda na položaju Kadina Glavica. ${ }^{23} \mathrm{~S}$ prostora Petrovoga polja poznata su tri spomenika pomoćne postrojbe ala Claudia Nova (HD034202; HD058349; HD062295). Logor za njenoga kratkog boravka u Dalmaciji mogao je biti smješten na prostoru Kadine Glavice (Glavaš 2015: 32). Razlog toj pretpostavci leži u koncentraciji spomenika njenih pripadnika na prostoru Petrova polja. ${ }^{24}$ Ala Claudia Nova, kako sugerira njezino ime, bila je ustrojena za vrijeme cara Klaudija (41. - 54. god.), a zahvaljujući vojnoj diplomi $(\mathrm{CIL} 16,20)$ koja potvrđuje njeno prisustvo u Germaniji 74. god., pretpostavljamo da tada više nije boravila u Dalmaciji. ${ }^{25} \mathrm{Na}$ istome prostoru nalazimo i spomenik pripadnika cohors I Lucensium (HD061686). ${ }^{26} \mathrm{~S}$ Kadine Glavice potječe i zavjetni žrtvenik konjaničkoga dekuriona (HD062412) postrojbe cohors III Alpinorum equitata koja je, kako se smatra, u ranome flavijevskom razdoblju boravila na toj poziciji, da bi kasnije bila premještena u kastel Bigeste (Cambi et al. 2007: 30; Miletić 2010: 132; Glavaš 2015: 42). ${ }^{27}$

Na području Muća, posebice Gornjeg Muća (antički Andetrium), epigrafski je tijekom 1. st. stoljeća zabilježena nazočnost više rimskih postrojbi. ${ }^{28}$ Tako dva nadgrobna natpisa (HD061927; HD054442) spominju osmu dobrovoljačku kohortu (cohors VIII voluntariorum civium Romanorum) koja je boravila, kako smatraju neki istraživači, najprije u kastelu u Andetriju pa u logoru Tilurium nakon odlaska sedme legije iz provincije Dalmacije (Alföldy 1987: 254; Matijević 2009a: 45; Glavaš 2015: 59). U Andetriju je duže vremena boravila i cohors III Alpinorum (Alföldy 1987: 246; Cambi et al. 2007: 30; Miletić 2010: 132; Glavaš 2015: 43). Jedan nadgrobni spomenik (HD061926) i jedan zavjetni žrtvenik (HD008787) pronađeni u Donjem Muću, datirani do 2. st., govore o dugotrajnijem boravku te jedinice $u$ Andetriju. $U$ Andetriju je pronađen i zavjetni žrtvenik jednoga centuriona (HD060571), međutim, kako je tek djelomično sačuvan, nije sigurno je li pripadao postrojbi legio VII ili XI Claudia pia fidelis.

Kasteli koji su navodno postojali između legijskih logora

23 Odnedavno se na prostoru Kadine Glavice vrše arheološka istraživanja koje provodi Odjel za arheologiju Sveučilišta u Zadru. Preliminarni rezultati istraživanja predstavljeni su na znanstvenome skupu $24^{\text {th }} \mathrm{In}-$ ternational Limes Congress. Vidi: Miletić, Bekavac 2018: 39.

24 I. Glavaš (2015: 32) navodi da se s ovim prostorom može povezati četiri spomenika te ale (od 8 sveukupno dokumentiranih u Dalmaciji), međutim jedan od spomenika (CIL 03,9797) ne navodi izričito ovu postrojbu, već samo riječ ala.

25 Za različita mišljenja o njenom boravku u Dalmaciji vidi: Wilkes 1969: 471; Alföldy 1987: 242; Glavaš 2015: 31.

26 Za različita mišljenja o njenom kretanju i vremenu boravka u Dalmaciji vidi: Alföldy 1987: 253; Wilkes 1969: 473; Glavaš 2015: 51.

27 G. Alföldy (1987: 245) smatra da je kohorta u provinciji od ustanka Batona. N. Cambi (et al. 2007: 30) i Ž. Miletić (2010: 131-135) postrojbu cohors III Alpinorum smještaju u pomoćni logor Burn između 60. i 70. god.

28 Na području Muća do sada se nisu provodila sustavna arheološka istraživanja, međutim, L. Bekić nekoliko je puta obišao taj prostor te proučio pokretne nalaze koji su bili dostupni u arheološkim muzejima u Splitu i Zagrebu. Bekić zaključuje da sačuvani pokretni arheološki materijal svjedoči o prisutnosti vojske i civila. Vidi: Bekić 2002; 2011: 315-325. the wider time frame for both would be, according to researchers, the second half of the $1^{\text {st }}$ cent. (Cambi et al. 2007: 31-32; Miletić 2010: 132, 134; Glavaš 2015: 51-56).

Southeast from Burnum lies Petrovo Polje, a fertile plain where the existence of antique sites of Promona (Tepljuh), Magnum (Balina glavica) were assumed, along with an auxiliary fort on the modern-day position of Kadina Glavica. ${ }^{23}$ Three monuments set up by members of the ala Claudia No$v a$ originate from the territory of Petrovo polje (HD034202; HD058349; HD062295). It seems that the unit's auxiliary fort, while it was briefly stationed in Dalmatia, could have been located in Kadina Glavica (Glavaš 2015: 32.) The reason for this assumption lies in the concentration of monuments of its members in the area of Petrovo polje. ${ }^{24}$ Ala Claudia Nova, as is presumed by its name, was formed under Emperor Claudius (41 - $54 \mathrm{AD}$ ), and thanks to a military diploma (CIL $16,20)$ confirming her presence in Germania in $74 A D$ we assume that it was no longer stationed in Dalmatia at that time. ${ }^{25}$ From this area also originates a monument of cohors I Lucensium (HD061686). ${ }^{26}$ The altar of a cavalry decurion (HD062412) confirms the presence of the cohors III Alpinorum equitata in Kadina Glavica, which most probably resided there in the early Flavian period and was later moved to the fort at Bigeste (Cambi et al. 2007: 30; Miletić 2010: 132; Glavaš 2015: 42).27

In the area of Muć, especially in Gornji Muć (ancient Andetrium), during the $1^{\text {st }}$ cent. $A D$, the presence of several Roman military units is epigraphically attested. ${ }^{28}$ Two tombstones (HD061927; HD054442) mention the cohors VIII voluntariorum civium Romanorum, which was firstly garrisoned in the fort at Andetrium, and was, after the departure of legio VII, transferred to the fortress at Tilurium (Alföldy 1987: 254; Matijević 2009a: 45; Glavaš 2015: 59). Cohors III Alpinorum resided in Andetrium for a longer period of time (Alföldy 1987: 246; Cambi et al. 2007: 30; Miletić 2010: 132; Glavaš 2015: 43). The tombstone (HD061926) and the sacrificial altar (HD008787), that were found in Donji Muć and were dated until the $2^{\text {nd }}$ cent., point to the long-term stay of this military unit there. The altar erected by one centurio (HD060571) was also found in Andetrium, however, as it is

23 Since recently, in the area of Kadina Glavica archaeological research is being conducted by the Department of Archeology at the University of Zadar. The preliminary results of the research were presented at a scientific conference $24^{\text {th }}$ International Limes Congress. See: Miletić, Bekavac 2018: 39.

24 I. Glavaš (2015: 32) states that this area can be linked to four monuments of this ala (out of eight documented in Dalmatia). One of the monuments he mentions (CIL 03, 9797), unfortunately, does not explicitly state this unit, but only the word ala.

25 For different views on its time in Dalmatia see: Wilkes 1969: 471; Alföldy 1987: 242; Glavaš 2015: 31.

26 For views on its movement across different garrisons and time in Dalmatia see: Alföldy 1987: 253; Wilkes 1969: 473; Glavaš 2015: 51.

27 According to G. Alföldy (1987: 245) the cohors arrived in Dalmatia during the Bellum Batonianum. N. Cambi (et al. 2007: 30) and Ž. Miletić (2010: 131-135) assume the cohors III Alpinorum resided in the auxiliary fort at Burnum between 60 and $70 \mathrm{AD}$.

28 In the area of Muć, no systematic archaeological research has yet been conducted. However, L. Bekić examined the area several times and went through available small finds from the archaeological museums in Split and Zagreb. Bekić concluded that the finds point to military and civil presence in the area. See: Bekić 2002; 2011: 315-325. 
Burnum i Tilurium nisu potvrđeni arheološki jer se nisu nikad iskopavali. Istraživači raspravljaju o njihovome postojanju na temelju izvora, antičkih karata i tekstova s kamenih spomenika, zbog čega su nam poznate njihove približne pozicije, no još uvijek to treba biti utvrđeno i na terenu. ${ }^{29}$

Rimski vojni logor Tilurium, koji se nalazi na prostoru današnjeg sela Gardun, podigli su Rimljani na sjeveroistočnome dijelu visoravni koja se uzdiže iznad desne obale rijeke Cetine koja predstavlja i prirodnu zapreku putnim pravcima prema istoku i sjeveroistoku. Važnost ovoga pravca primijećena je i u najdavnijim vremenima, pa je i Rimljanima bilo jasno da preko Cetine vode važne komunikacije kako za promet roba, tako i za protok ljudi. Rimljani su tu strateški važnu komunikaciju zaštitili gradnjom vojnoga logora Tilurium s čijeg se dominantnoga i strateškoga mjesta pruža pogled kako na rijeku Cetinu i prijelaze preko nje, tako i na sva okolna polja i visoravni kao što se moglo nadgledati i prometnice. Tilurium se nije nikad razvio u civilno naselje, pa se odlaskom vojske umanjio i njegov značaj. Arheološka istraživanja koje su provode u Tiluriju pokazala su se nevjerojatno uspješnima. Iznijela su na svjetlo dana obrise nekadašnje utvrde kao i brojne pokretne nalaze što je omogućilo bolje razumijevanje nekadašnjih događaja. ${ }^{30} \mathrm{Na}$ temelju epigrafskih izvora, smatra se da je prva legija koja je trajno boravila u legijskom logoru Tiluriju bila legio VII (od 42. god. poznata kao legio VII Claudia pia fidelis) (Zaninović 1996c: 280-281, 284; Sanader, Tončinić 2010: 38, 45; Tončinić 2011). S područja grada Trilja, kao i sela Košute i Vojnić Sinjski, poznato je najmanje 16 epigrafskih spomenika vojnika VII legije. ${ }^{31}$ Uz njih, pronađena su u Trilju i dva natpisa pripadnika legio XI (HD058818; HD058879). Iz vremena 1. st. potječe i po jedan spomenik pripadnika postrojbi cohors /l Cyrrhestarum, cohors III Alpinorum, ala Claudia Nova i ala Frontoniana. ${ }^{32}$ Ala Tungrorum Frontoniana stacionirana je u Dalmaciji kratko tijekom flavijevskoga razdoblja, dok je potvrđena u Panoniji već u 80. god. (Wilkes 1969: 471; Alföldy 1987: 243; Glavaš

29 U antičkim itinerarima, literarnim i epigrafskim izvorima spominju se Promona, Magnum i Andetrium. Projekt Hrvatske zaklade za znanost Razumijevanje rimskih granica: primjer istočnog Jadrana (AdriaRom) (financiranje: Hrvatska zaklada za znanost, voditelji: dr. sc. Mirjana Sanader i dr. sc. Domagoj Tončinić) ima, između ostaloga, za cilj provesti sveobuhvatna arheološka istraživanja kako bi se prikupile sve relevantne informacije o ovim lokalitetima.

30 Detaljnije o samim arheološkim istraživanjima: Sanader 2003; Sanader, Tončinić 2010; Šimić Kanaet 2010; Tončinić 2011; Sanader et al. 2014; Sanader et al. 2017.

31 HD028177; HD034294; HD039866; HD040156; HD040157; HD051028; HD054439; HD058787; HD058789; HD058819; HD058840; HD058848; HD058854; HD058855; HD058869; HD062415. D. Tončinić (2011: 170), osim gore navedenih spomenika, kao moguće spomenike sedme legije, zahvaljujući stilsko-ikonografskim obilježjima i pretpostavkama u ranijoj literaturi, navodi još sedam nadgrobnih stela pronađenih na širem području Tilurija. To su: HD034293; HD058783; HD034287; HD061690; HD051029; HD034296 i HD034182. Blizu području grada Trilja, u Dicmu, pronađen je jedan nadgrobni natpis pripadnika VII. legije: HD022811. Za cjelovitu raspravu o spomenicima legio VII na području provincije Dalmacije vidi: Tončinić 2011.

32 Cohors III Alpinorum: HD028180; Cohors II Cyrrhestarum: HD028183; Ala Frontoniana: HD046617; Ala Claudia Nova: HD054440. only partially preserved, it is uncertain whether it belonged to the member of legio VII or legio XI Claudia pia fidelis.

The forts that allegedly existed between the legionary fortresses Burnum and Tilurium have not been archaeologically confirmed since they were never excavated. Researchers discuss their existence on the basis of ancient literary or epigraphic sources and antique maps. Approximate positions of these forts are known, yet the exact location still needs to be determined. ${ }^{29}$

The legionary fortress Tilurium is located in the area of the modern village of Gardun. It was built by the Romans in the northeastern part of a plateau that rises above the right bank of the Cetina river, which represents a natural obstacle to travel directions to the east and northeast. Naturally, the significance of this route was plain already in ancient times, so it was also clear to the Romans that important communications, traffic of goods and people go over Cetina. The Romans protected this strategically important route by constructing a legionary fortress Tilurium, whose dominant and strategic location provided a lookout over the river Cetina and crosses over it, as well as the surrounding fields, plateaus, and roads. With later departure of the army, importance of Tilurium diminished, as it never developed into a civil settlement. The archaeological research carried out in Tilurium proved to be incredibly successful. It revealed the outlines of the fortress as well as numerous archaeological finds that enabled a better understanding of past events. ${ }^{30}$ Based on the epigraphic sources it is assumed that the first legion to reside in the legionary fortress Tilurium was legio VII (from 42 AD known as legio VII Claudia pia fidelis) (Zaninović 1996c: 280-281, 284; Sanader, Tončinić 2010: 38, 45; Tončinić 2011). At least sixteen monuments mentioning this legion were found in the territory of the town of Trilj, i.e. from the villages, Košute and Vojnić Sinjski. ${ }^{31}$ In addition to them, two inscriptions of members of the legio XI were found (HD058818; HD058879). From the period of the $1^{\text {st }}$ cent., a single monument of the members of units cohors II Cyrrhestarum, cohors III Alpinorum, ala Claudia Nova and ala Frontoniana were found..$^{32}$ Ala Tungrorum Frontoniana stayed in Dalmatia shortly during the Flavian period, while it was confirmed in Pannonia already in 80 AD (Wilkes 1969:

29 Ancient itineraries, literary and epigraphic sources mention Promona, Magnum and Andetrium. The Croatian Science Foundation research project Understanding Roman Borders. The Case of the Eastern Adriatic (AdriaRom) (founding: Croatian Science Foundation, led by prof. dr. M. Sanader and dr. D. Tončinić), among other things, aims to carry out a comprehensive archaeological research in order to collect all relevant information on these sites.

30 More about the archeological research itself: Sanader 2003; Sanader, Tončinić 2010; Šimić Kanaet 2010; Tončinić 2011; Sanader et al. 2014; Sanader et al. 2017.

31 HD028177; HD034294; HD039866; HD040156; HD040157; HD051028 HD054439; HD058787; HD058789; HD058819; HD058840; HD058848; HD058854; HD058855; HD058869; HD062415. Aside from these monuments, D. Tončinić (2011: 170) offers seven additional tombstones which could possibly be attributed to the Seventh legion based on style and iconography, as well as contributions from earlier literature. Those are: HD034293; HD058783; HD034287; HD061690; HD051029; HD034296 i HD034182. A tombstone of a member of the legio VII was found in the area of Dicmo, located in the vicinity of the town of Trilj: HD022811. For a complete work on monuments of the Seventh legion from the province of Dalmatia see: Tončinić 2011.

32 Cohors III Alpinorum: HD028180; Cohors II Cyrrhestarum: HD028183; Ala Frontoniana: HD046617; Ala Claudia Nova: HD054440. 
2015: 39). ${ }^{33}$ U Tilurij krajem 1. st. dolazi cohors VIII voluntariorum civium Romanorum koja je, ako je suditi po osam sačuvanih natpisa, na tome području boravila više od stoljeća i pol. ${ }^{34}$

Prisutnost spomenutih vojnih jedinica dokumentirana je epigrafskim spomenicima, kao i arheološkim istraživanjima Burna i Tilurija, dok je na drugim lokalitetima zbog nepostojanja istraživanja dokumentirana isključivo epigrafskim spomenicima. Analiza sakupljenih podataka o teritorijalnoj rasprostranjenosti vojnika i vojnih postrojbi širega područja između legijskih logora Burnum i Tilurium u 1. st. pokazuje
471; Alföldy 1987: 243; Glavaš 2015: 39). ${ }^{33}$ At the end of the $1^{\text {st }}$ cent. cohors VIII voluntariorum civium Romanorum came to Tilurium, leaving us eight inscriptions in this area for the next more than a century and a half. ${ }^{34}$

The presence of aforementioned military units is documented by epigraphic and archaeological researches at Burnum and Tilurium, while due to the lack of research the other sites are documented only by epigraphic monuments. The analysis of the collected data on the territorial distribution of soldiers and military units of the wider area between the legionary fortresses Burnum and Tilurium in the $1^{\text {st }}$ cent. showed their concentration on the earlier in the

\begin{tabular}{|c|c|c|}
\hline POSTROJBA / MILITARY UNIT & LOKALITET / FIND-SITE & OBJAVA / PUBLICATION \\
\hline \multirow[t]{2}{*}{ legio XI Claudia pia fidelis } & Burnum & $\begin{array}{l}\text { HD004410; D025909; HD028011; HD028171; HD028174; } \\
\text { HD031512; HD031659; HD034385; HD034386; HD034387; } \\
\text { HD034388; HD034389; HD035392; HD035397; HD039871; } \\
\text { HD039872; HD039870; HD055081; HD058137; HD058165; } \\
\text { HD058166; HD058168; HD058294; HD058296; HD058298; } \\
\text { HD061350; HD061352; HD061355; HD061407; HD061473 }\end{array}$ \\
\hline & Tilurium & HD058818; HD058879 \\
\hline \multirow[b]{2}{*}{ legio VII Claudia pia fidelis } & Burnum & HD061333 \\
\hline & Tilurium & $\begin{array}{l}\text { HD028177; HD034294; HD039866; HD040156; HD040157; } \\
\text { HD051028; HD054439; HD058787; HD058789; HD058819; } \\
\text { HD058840; HD058848; HD058854; HD058855; HD058869; } \\
\text { HD062415 }\end{array}$ \\
\hline \multirow{2}{*}{$\begin{array}{l}\text { cohors VIII voluntariorum } \\
\text { civium Romanorum }\end{array}$} & Andetrium & HD061927; HD054442 \\
\hline & Tilurium & $\begin{array}{l}\text { HD012375; HD033012; HD050511; HD058839; HD058589; } \\
\text { HD050511; HD055191; HD028864. }\end{array}$ \\
\hline \multirow{2}{*}{ cohors II Cyrrhestarum } & Burnum & HD025912; HD034391; HD065347 \\
\hline & Tilurium & HD028183 \\
\hline \multirow{2}{*}{ ala Claudia Nova } & Petrovo polje & HD034202; HD058349; HD062295 \\
\hline & Tilurium & HD054440 \\
\hline \multirow{3}{*}{ cohors III Alpinorum } & Petrovo polje & HD062412 \\
\hline & Andetrium & HD008787 \\
\hline & Tilurium & HD028180 \\
\hline cohors I Montanorum & Burnum & HD034390; HD035403 \\
\hline legio XX Valeria Victrix & Burnum & HD061408 \\
\hline legio VIII Augusta & Burnum & HD035401 \\
\hline ala I Hispanorum & Burnum & HD011485 \\
\hline ala Frontoniana & Tilurium & HD046617 \\
\hline cohors I Lucensium & Petrovo polje & HD061686 \\
\hline
\end{tabular}

Tab. 1 Spomenici vojnih postrojbi između Burna i Tilurija u 1. stoljeću (izradili: M Vukov i D. Bužanić)

Tab. 1 Monuments of military units between Burnum and Tilurium in the $1^{\text {st }}$ century (made by: M Vukov i D. Bužanić)

njihovu koncentraciju na ranije u tekstu spomenutoj svojevrsnoj liniji koja prati obalu, odnosno smjer pružanja Dinare.

33 Za raspravu o postojanju dvije različite ale na području Dalmacije pod nazivima ala Tungrorum i ala Tungrorum Frontoniana vidi: Cesarik 2014: 1-24.

34 HD012375; HD033012; HD050511; HD058839; HD058589; HD050511; HD055191; HD028864. text mentioned line that follows the coast, i.e. the direction of the Dinara mountain.

33 For a discussion of the existence of two different units in Dalmatia under the names ala Tungrorum and ala Tungrorum Frontoniana see: Cesarik 2014: 1-24.

34 HD012375; HD033012; HD050511; HD058839; HD058589; HD050511; HD055191; HD028864. 


\section{ZAKLJUČAK}

Rimljani su bili svjesni da jedino mir može donijeti i ekonomski napredak koji ima blagotvorni utjecaj na rimske građane, pa slijedom toga i na one koji stoje na njihovom čelu. Stoga su oni nastojali uvesti mir u svim krajevima kojima bi zavladali, pa tako i u lliriku. Na području između legijskih logora Burnum i Tilurium ne bi bilo moguće djelovati na uspostavi mira bez nazočnosti vojske. Vojska je najprije na brutalan način upravo tu ugušila otpor indigenoga stanovništva, nakon čega se nije povukla, nego je i desetljećima ostala u tim krajevima. Upravo je stalna prisutnost vojnika u gradovima, naseljima, na cestama i mostovima bila ključnim i uznemirujućim faktorom koji je činio da domaće stanovništvo više ne razmišlja o pobuni i otporu. Ne manje uznemirujući mogao je biti i pogled na rimske vojničke utvrde koje su uz važne ceste bile podignute u zaleđima gradova. Visoki i široki kameni bedemi s brojnim masivnim i moćnim kulama karakterizirali su legijske logore na Rajni i Dunavu, pa tako i legijske logore Burnum i Tilurium. Iz njihovih se kula moglo promatrati okolicu, ali su se njihove visoke kule i čvrsti bedemi isto tako mogli vidjeti iz daleka i ulijevati strah. Tim više što nitko od domaćih stanovnika nije mogao ni znao sagraditi takvu utvrdu, a pogotovo je nije znao uništiti. Osim toga, među narodom su se šuljali rimski špijuni koji su uvijek iznova podsjećali na rimske pobjede i odmazde koje su pobunjenici mogli očekivati. Kako smo vidjeli iz ove rasprave, Rimljani su postigli mir na području između Jadera i Salone, mir koji su postigli ratom, a održavali su ga, barem prvih pola stoljeća, zastrašivanjem ratom.

\author{
Prijevod / Translation \\ Mirna Vukov, Domagoj Bužanić \\ Lektura / Proofreading \\ Marko Maras
}

\section{CONCLUSION}

The Romans were aware that only peace can bring economic progress, which in turn had a beneficial effect on Roman citizens and consequently to those who stand over them. Therefore, they sought to bring peace in all regions they ruled over, and thus in Illyricum. In the area between the legionary fortresses Burnum and Tilurium, it would not be possible to act on establishing peace without the presence of the army. The army brutally suffocated the resistance of indigenous people, after which it did not retreat but remained for decades in these areas. The constant presence of soldiers in the cities and settlements, above roads and bridges was key and a disturbing factor that made the local population no longer think about rebellion and resistance. No less disturbing was the view on Roman fortresses and forts, which were erected in the hinterland of cities and located along important roads. High and wide stone ramparts with many massive and powerful towers characterized the legionary fortresses on the Rhine and Danube, but also the legionary fortresses Burnum and Tilurium. Out of these tall towers, one could observe the surrounding area, but those towers along with strong walls could have also been seen from afar and produce the effect of fear. This is especially the case since the local population wasn't able to build such a fortress, much less destroy it. In addition to this, Roman spies were among the people and repeatedly reminded them of Roman victories and retaliation the rebels could expect. As we could see from this discussion, the Romans have reached peace in the area between lader and Salona. The peace they have achieved by war, and they maintained it, at least for the first half of the century, by intimidating with the notion of war. 


\section{KRATICE / ABBREVIATIONS}

CIL - Corpus Incriptionum Latinarum, Berlin.

HD - Epigraphische Datenbank Heidelberg (Heidelberger Akademie der Wissenschaften; http://edh-www.adw.uni-heidelberg.de/ home).

\section{IZVORI / SOURCES}

Bird, H. W. (ed.) 1994, Aurelius Victor: De Caesaribus, Translated Texts for Historians 17, Liverpool University Press, Liverpool.

Büttner Wobst, Th. (ed.) 1904, Polybius, Historiae, Teubner, Lipsiae.

Cary, E. (ed.) 1917, Dio Cassius, Roman History, Vol. VI: Books 51-55, Loeb Classical Library 83, Harvard University Press, Cambridge.

Cary, E. (ed.) 1924, Dio Cassius, Roman History, Vol. VII: Books 56-60, Loeb Classical Library 175, Harvard University Press, Cambridge.

Hainseelin, P., Watelet, H. (eds.) 1932, Velleius Paterculus et Florus, Historiae romaine, Classiques Garnier, Paris.

Ian, L., Mayhoff, C. (eds.) 1906, Plinius, Naturalis Historia, Teubner, Lipsiae. Kostović, J. (ed.) 1970, Tacit, Anali, Matica hrvatska, Zagreb.

Matijašić, R. (ed.) 2007, Djela Božanskog Augusta, Latina et Graeca 58, Zagreb.

Miller, K. (ed.) 1888, Tabula Peutingeriana, Weltkarte des Castorius, Ravensburg.

Miklić, J. (ed.) 1987, Tacit. Historije, Latina et Graeca 12, Zagreb.

Miklić, J. (ed.) 2006, Gaj Velej Paterkul, Rimska povijest, Latina et Graeca 57 , Zagreb.

Pinder, M., Parthey, G. (eds.) 1860, Ravennatis Anonymi Cosmographia et Guidonis Geographica, Berlin.

Roth, C. L. (ed.) 1882, Suetonius Tranquillus, De Vita Caesarum, Teubner, Lipsiae.

Zangemeister, C. (ed.) 1889, Pauli Orosii historiarum adversum paganos libri VII, Bibliotheca scriptorum Graecorum et Romanorum Teubneriana, Leipzig.

Weissenborn, W. (ed) 1906, Titus Livius, Ab Urbe condita, Teubner, Lipsiae.

\section{LITERATURA / BIBLIOGRAPHY}

Alföldy, G. 1987, Römische Heeresgeschichte: Beiträge 1962-1985., J. C. Gieben, Amsterdam.

Alföldy, G. 1989, Zu den Inschriften der Legio VIII. Augusta in Dalmatia, Vjesnik za arheologiju i historiju dalmatinsku, Vol. 82, 201-207.

Baatz, D. 1993, Der römische Limes. Archäologische Ausflüge zwischen Rhein und Donau, Gebr. Mann Verlag, Berlin.

Bekić, L. 2002, Ilirski i rimski Andetrij, Unpublished Master's thesis, University of Zagreb, Zagreb.

Bekić, L. 2011, Andetrij, rimsko vojno uporište. Topografske odrednice, in: Arheološka istraživanja u Cetinskoj krajini. Radovi kolokvija Rimska vojska u procesu romaniziranja provincije Dalmacije, Sinj, 13. 10. 2006, Izdanja Hrvatskog arheološkog društva 27, Zagreb-Sinj, 315-321.

Bishop, M. 2012, Handbook to Roman Legionary Fortresses, Pen \& Sword Books Ltd, Barnsley.

Bojanovski, I. 1974, Dolabelin sistem cesta u rimskoj provinciji Dalmaciji, Djela Akademije nauka i umjetnosti Bosne i Hercegovine, knj. 47, Sarajevo.

Bojanovski, I. 1990, Legio VIII Augusta u Dalmaciji, Arheološki vestnik, Vol. $41,699-712$.

Breeze, D. J., Jilek, S. (eds.) 2008, Frontiers of the Roman Empire. The European dimension of a world heritage site, Historic Scotland, Edinburgh.

Britvić, J. 1971, Neka topografsko-povijesna pitanja s teritorija Delmata, Vjesnik za arheologiju i historiju dalmatinsku, Vol. 65-67 (19631965), 27-35.

Bulić, F. 1903, Cenni sulla strada romana di Salona alla Colonia Claudia Aequum (Čitluk presso Sinj) e sue diramazioni, Bullettino di archaeologia e storia dalmata, Vol. 26, 113-129.

Cabanes, P. 1983, Notes sur les origines de l'intervention romaine sur la rive orientale de la mer Adriatique, 229-228 avant J. C., in: Atti del Convegno L'Adriatico tra Mediterraneo e Penisola Balcanica nell'antichità, Lecce - Matera 21 al 27 ottobre 1973, Istituto per la storia e l'archeologia della Magna Grecia, Taranto, 187-204.

Cabanes, P. 1988, Les Illyriens de Bardylis \& Genthios (IVe-lle siecles avant J.-C.), Regards sur I'histoire 65, Paris.
Cambi, N. 1994, Stele iz kasnoantičke grobnice u Dugopolju, Vjesnik za arheologiju i historiju dalmatinsku, Vol. 86 (1993), 147-181.

Cambi, N., Glavičić, M., Maršić, D., Miletić, Ž., Zaninović, J. 2007, Rimska vojska u Burnumu / L'esercito romano a Burnum, Gradski muzej Drniš, Javna ustanova "Nacionalni park Krka", Drniš-Šibenik-Zadar.

Campbell, B. 2002, War and society in Imperial Rome 31 BC-AD 284, Routledge, London-New York

Cesarik, N. 2014, Osvrt na itinerar ale Tungra i Frontonove ale, Radovi Zavoda za povijesne znanosti Hrvatske akademije znanosti i umjetnosti u Zadru, Vol. 56, 1-24.

Cesarik, N. 2018, River Crossings and Roman Auxiliary Forts: The Evidence from the River Cetina, Collegium antropologicum, Vol. 42 No. $1,53-63$.

Cesarik, N. 2019, The presence of legio XX in Illyricum: a reconsideration, The Classical Quarterly, Vol. 69, 278-289. https://doi.org/10.1017/ S0009838819000247

Coppola, A. 1999, Ottaviano e la Dalmazia: imitatio Alexandri, aemulatio Caesaris, in: La Dalmazia e l'altra sponda. Problemi di "Archaiologhì» adriatica, Braccesi L., Graciotti S. (eds.), Firenze, 195-212. https://doi.org/10.1017/S0009838819000247

Džino, D. 2009, The Bellum Batonianum in Contemporary Historiographical Narratives, Arheološki radovi i rasprave, Vol. 16, 29-45.

Fortis, A. 1984, Put po Dalmaciji (priredio J. Bratulić), Globus, Zagreb.

Glavaš, I. 2015, Vojno značenje cesta u rimskoj provinciji Dalmaciji za principata, Unpublished PhD thesis, University of Zadar, Zadar.

Gunjača, S. 1949, Nov prinos ubikaciji Tiluriuma, Vjesnik za arheologiju i historiju dalmatinsku, Vol. 52, 50-52.

Hammond, N. G. L. 1968, Illyris, Rome and Macedon 229-205 B.C., The Journal of Roman Studies, Vol. 58, 1-21. doi: 10.2307/299691

Heilmeyer, W. D., La Rocca, E., Martin, H. G. (eds.) 1988, Kaiser Augustus und die verlorene Republik, Verlag Philipp von Zabern, Mainz. doi: $10.2307 / 299691$

Johnson, A. 1987, Römische Kastelle des 1. und 2. Jahrhunderts n. Chr. in Britannien und in den germanischen Provinzen des Römerreiches, Kulturgeschichte Antike Welt 37, Verlag Philipp von Zabern, Mainz.

Klose, G., Nünnerich-Asmus, A. 2006, Grenzen des Römischen Imperiums, Verlag Philipp von Zabern, Mainz.

Kolb, A., Walser, G. 2007, Corpus Inscriptionum Latinarum. XVII. Miliaria imperil Romani. Pars quarta. Illyricum et provinciae Europae 
Graecae. Fasciculus 1. Miliaria provinciarum Raetiae et Norici, W. de Gruyer, Berlin-New York.

Lörincz, B. 2001, Die römische Hilfstruppen in Pannonien während der Prinzipatszeit, Forschungsgesellschaft Wiener Stadtarchäologie, Wien.

Matijašić, R. 2009, Povijest hrvatskih zemalja u antici do cara Dioklecijana, Leykam international, Zagreb.

Matijević, I. 2009a, Cohors VIII Voluntariorum civium Romanorum i neki njezini pripadnici u službi namjesnika provincije Dalmacije, Tusculum - časopis za solinske teme, Vol. 2 No. 1, 45-58.

Matijević, I. 2009b, Dva neobjavljena natpisa Druge kohorte Kiresta iz Dalmacije, Diadora, Vol. 23, 35-43.

Mesihović, S. 2013, Baton - prilozi istraživanju naše ilirske i antičke baštine, Gradina, Vol. 2, 2013, 21-136.

Miletić, Ž. 1993, Rimske ceste između Jadera, Burnuma i Salone, Radovi Filozofskog fakulteta u Zadru, Vol. 32 (19), 117-150.

Miletić, Ž. 2006, Roman Roads along the Eastern Coast: State of Resear$\mathrm{ch}$, in: Les routes de l'Adriatique antique - Geographie et economie, Čače S., Kurilić A., Tassaux F. (eds.), AUSONIUS-PESSAC, Bordeaux-Zadar, 125-136.

Miletić, Ž. 2010, Burnum - vojničko središte provincije Dalmacije, in: Nalazi rimske vojne opreme u Hrvatskoj, Radman-Livaja I. (ed.), Arheološki muzej u Zagrebu, Zagreb, 113-176.

Miletić, Ž. 2011, Production of tegulae in Burnum in the context of building activities, in: Rimske keramičarske i staklarske radionice. Proizvodnja i trgovina na jadranskom prostoru, Crikvenica 23. - 24. 10. 2008., Zbornik I. međunarodnog arheološkog kolokvija, Lipovac Vrkljan G., Radić Rossi I., Šiljeg B. (eds.), Institut za arheologiju, Grad Crikvenica, Muzej grada Crikvenice, Crikvenica, 263-277.

Miletić, Ž., Bekavac, S. 2018, Octavian's Footprints: Hillforts, camps and roads between Burnum and Synodium, in: $24^{\text {th }}$ International Limes Congress, Serbia, September 2018. Book of Abstracts, Korač M. (ed.), Institute of Archaeology, Belgrade, 39.

Pejnović, D. 2002, Istra, Južno hrvatsko Primorje - Dalmacija, in: Veliki atlas Hrvatske, Borovac I. (ed.), Mozaik knjiga, Zagreb, 301-335.

Periša, D. 2008, Je li delmatsko područje presjekao rimski limes?, Archaeologia Adriatica, Vol. 2 No. 2, 507-517.

Planck, D., Thiel, A. 2009, Das Limes-Lexikon. Roms Grenzen von A bis Z, Beck'sche Reihe, München.

Radić Rossi, I. 2017, Proučavanje promjena morske razine na arheološkim nalazištima u priobalju / The study of sea-level changes at coastal archaeological sites, Vjesnik za arheologiju i historiju dalmatinsku, Vol. 110. No. 2, 549-576.

Ramsay, W. 1941, The Social Basis of Roman Power in Asia Minor, Aberdeen University Press, Aberdeen.

Sanader, M. 2002, Tilurium, Burnum and Bigeste. A new contribution to the dating of the Delmataen limes, in: Limes XVIII: Proceedings of the XVIIIth International Congress of Roman Frontier Studies Held in Amman, Jordan, 02. - 11. 09. 2000., Freeman Ph., Bennett J., Fiema Z. T., Hoffmann B. (eds.), BAR International Series 1084 (II), Oxford, 713-718.

Sanader, M. 2003, Tilurium I. Istraživanja / Forschungen 1997 - 2001, Golden Marketing, Arheološki zavod Filozofskog fakulteta u Zagrebu, Zagreb.

Sanader, M. 2009, Dalmatia. Eine römische Provinz an der Adria, Verlag Philipp von Zabern, Mainz.

Sanader, M. 2015, Der Januskult in den Provinzen des Romischen Reiches unter besonderer Berucksichtigung der Ikonographie zweier Reliefs aus Dalmatien und Dakien, in: Cult and votive monuments in the Roman Provinces, Proceedings of the 13th International Colloquium on Roman Provincial Art, Bucharest - Alba lulia Constanța, 27.05.-03.06.2013, Corpus Signorum Imperii Romani, Alexandrescu C.-G. (ed.), Mega Publishing House, Cluj-Napoca, 139-147.
Sanader, M. 2018, Saltus Teutoburgiensis et Teutoburgium. Prilog istraživanju, in: M. Sanader, Rimljani između Mediterana i Dunava. Odabrani radovi iz antičke provincijalne arheologije, FF press, Arheološki zavod, Zagreb, 16-23.

Sanader, M., Tončinić, D. 2010, Gardun - antički Tilurium / Gardun - The Ancient Tilurium, in: Nalazi rimske vojne opreme u Hrvatskoj / The Finds of the Roman Military Equipment in Croatia, Radman-Livaja I. (ed.), Arheološki muzej u Zagrebu, Zagreb, 33-53.

Sanader, M. 2016, The Veteran's Colony Aequum, the Legionary Fortress Tilurium and the Sinj Field. Re-examining Old Problems, Nova antička Duklja, Vol. VII, 39-54.

Sanader, M., Tončinić, D., Šimić Kanaet, Z., Buljević, Z., Ivčević, S., Šeparović, T. 2014, Tilurium III. Istraživanja 2002 - 2006. godine, I - II, Dissertationes et monographiae 6, Filozofski fakultet Sveučilišta u Zagrebu, Arheološki zavod, Zagreb.

Sanader, M., Tončinić, D., Šimić Kanaet, Z., Ivčević, S., Buljević, Z., Šeparović, T., Miloglav, I. 2017, Tilurium IV. Istraživanja 2007-2010. godine, Dissertationes et monographiae 7, Filozofski fakultet Sveučilišta u Zagrebu, Arheološki zavod, Zagreb.

Schallmayer, E. 2005, Der Limes. Geschichte einer Grenze, Beck'sche Reihe, Wissen.

Schmitthenner, W. 1958, Octavians militärische Unternehmungen in den Jahren 35 - 33 v. Chr. Historia: Zeitschrift für Alte Geschichte, Vol. 7(2), 189-236.

Southern, P. 2007, The Roman army, A Social and Institutional History, Oxford University Press, Oxford.

Šašel, J. 1974, Die Limes-Entwicklung in Illyricum, in: Actes IXe Congrès International d'Etudes sur les Frontières Romaines, Mamaia, 06.13.09.1972., Pippidi D. M. (ed.), Bucureşti-Köln-Vienn, 194-199.

Šašel, J. 1992, Die Limes-Entwicklung in Illyricum, in: Opera Selecta, Šašel J., Bratož R., Šašel-Kos M. (eds.), Situla 30, Narodni muzej, Ljubljana, 397-403.

Šimić Kanaet, Z. 2010, Tilurium II. Keramika 1997 - 2006, I - II, Golden marketing-Tehnička knjiga, Zagreb.

Tončinić, D. 2009, Ziegelstempel römischer Militäreinheiten in der Provinz Dalmatien, in: LIMES XX. Estudios sobre la frontera romana, Leon, 04.-11.09.2006., Cerdán Á., Hanel N., Martin E. (eds.), Consejo Superior de Investigaciones Cientificas, Polifemo, Madrid, 1447-1459.

Tončinić, D. 2011, Spomenici VII. legije na području rimske provincije Dalmacije / Monuments of Legio VII in the Roman Province of Dalmatia, Arheološki muzej u Splitu, Split.

Tončinić, D., Tabak, A., Librenjak, A. 2011, Rimski vojni pečati u Cetinskoj krajini, Arheološka istraživanja u Cetinskoj krajini. Radovi kolokvija Rimska vojska u procesu romaniziranja provincije Dalmacije, Sinj, 13.10.2006., Tončinić D. (ed.), Izdanja Hrvatskog arheološkog društva 27, Zagreb-Sinj, 361-379.

Torelli, M. 1988, Gesellschafts und Wirtschaftsformen der augusteischen Zeit: Der Conseus Italia, in: Kaiser Augustus und die verlorene Republik, Hofter M. (ed), Verlag Phillip von Zabern, Mainz, 23-48.

Wilkes, J. J. 1969, Dalmatia, Harvard University Press, Cambridge.

Wilkes, J. J. 1977, Augustan Limes in Illyricum?, Studien zu den Militärgrenzen Roms, II: Vorträge des 10. Internationalen Limeskongresses in der Germania Inferior, Xanten - Nijmegen, 13.-19.09.1974., Beihefte der Bonner Jahrbücher 38, Köln, 245-246.

Woolf, G. 1993, Roman Peace, in: War and Society in the Roman World, Rich J., Shipley G. (eds.), Psychology Press, London, 171-194.

Zaninović, M. 1996a, Rimska vojska u razvitku antike na našoj obali, in: M. Zaninović, Od Helena do Hrvata, Školska knjiga, Zagreb, 209-220.

Zaninović, M. 1996b, Burnum, in: Zaninović M., Od Helena do Hrvata, Školska knjiga, Zagreb, 272-279.

Zaninović, M. 1996c, Vojni značaj Tilurija u antici, in: M. Zaninović, Od Helena do Hrvata, Školska knjiga, Zagreb, 280-291.

Zaninović, M. 2015, Iliski ratovi, Školska knjiga, Zagreb. 